\title{
Kopīgās tendences Latvijas Universitātes un Latvijas Republikas vēsturē starp pasaules kariem
}

\author{
Common Trends Shared By the University of Latvia and \\ the Republic of Latvia Between the World Wars
}

\author{
Raimonds Cerūzis, Dr. hist. \\ Latvijas Universitātes Vēstures un filozofijas fakultātes asociētais profesors \\ Aspazijas bulvāris 5, Rīga, LV-1050 \\ E-pasts: Raimonds.Ceruzis@lu.lv
}

Rakstā aplūkota Latvijas akadēmiskās elites iesaiste nacionālās augstskolas (vēlākās Latvijas Universitātes) izveidē un attīstībā starp abiem pasaules kariem. Vēstures avoti liecina par ciešo kopsakaru starp augstskolas izveides un attīstības iezīmēm un kopīgo valsts vēsturi dažādās tās attīstības stadijās starpkaru periodā. Plašāk apskatīti tādi aspekti kā augstskolas nozīme jaunās valsts ideolog̣ijā, starpnacionālās attiecības, saimnieciski finansiālie aspekti, tostarp darbinieku darba apstākḷi un atalgojums, kā arī mācībspēku iesaiste politiskajās aktivitātēs gan parlamentārisma, gan autoritārisma posmā. Visi šie aspekti atspoguḷo atbilstošas tendences valstī kopumā. Īpaši izcelta atsevišḳu personību loma, jo augstskolas mācībspēki Latvijas valsts tapšanas laikā un autoritārisma periodā uzskatāmi par viedokḷu līderiem.

Atslēgvārdi: Rīgas Politehniskais institūts, Latvijas Augstskola, Latvijas Universitāte, starpnacionālās attiecības, vācbaltieši, politika, ideoloǵija, izglītība, pētniecība, studijas.

The article reflects on involvement of the Latvian academic elite in the establishment and development of the University of Latvia between the two world wars. Historical sources show a close connection between the features of the establishment and development of the university and the common history of the country at various stages of its development in the interwar period. The aspects such as the role of higher education in the ideology of the new state, interethnic relations, economic and financial aspects, including their wages and working conditions, and the involvement of academics in political activities during both the parliamentary and authoritarian stages are discussed in greater detail. All these aspects reflect the corresponding trends in the country. The role of individual personalities is especially highlighted, since the teaching staff of the university is considered to be the leader of opinion during the formation of the Latvian state and the period of authoritarianism. 
Keywords: Riga Polytechnical Institute, University of Latvia, international relations, interethnic relations, Baltic Germans, politics, ideology, education, research, study.

\section{Augstskolas un valsts attīstības sākumi}

Ideja par latviešu augstskolu dzima vēl pirms Latvijas Republikas proklamēšanas. Līdzīgi kā prasības pēc latviešu pašnoteikšanās, arī augstskolas vīziju latviešu inteliǵences aprindas aktīvi sāka apspriest pēc 1917. gada Februāra revolūcijas Krievijas impērijā. Šo ideju atbalstīja plašs spektrs latviešu politiķu - gan konservatīvāk orientētie, gan liberālās pilsoniskās aprindas, gan strādniecība un latviešu strēlnieki, kas simpatizēja sociāldemokrātiem un pat vēlākajiem lieliniekiem.

Valsts un pirmās augstskolas tapšanas gaita bija tiešām spraiga. Īsā laika posmā bija risinājušies daudzi un škietami haotiski notikumi, kas mainija Latvijas politiskās reālijas. Spilgti tas atainojās Rīgā esošās augstskolas piemērā - to par pamatu jaunas augstskolas izveidei izraudzijās visas varas. Proti, jau Pirmā pasaules kara pēdējās nedēḷās vācu okupācijas vara Rīgā uz Politehnikuma bāzes izveidoja Baltijas Tehnisko augstskolu (Baltische Technische Hochschule), tad Pētera Stučkas vadītā lielinieku padomju Latvijas valdība pārn̄ēma latviešu augstskolas ideju un ar 1919. gada 8. februāra dekrētu Politehnikuma vietā nodibināja Latvijas Augstskolu, savukārt Andrieva Niedras valdība pēc Rīgas atkarošanas no lieliniekiem 1919. gada 22. maijā atkal tajās pašās telpās atjaunoja vācu veidoto Tehnisko augstskolu, un visbeidzot sekoja Kārḷa Ulmaṇa Pagaidu valdības veidotās Latvijas Augstskolas atklāšana 28. septembrī. Neatkarības gados no šīs plejādes kā Latvijas Augstskolas (vēlākās
Latvijas Universitātes - LU) priekštece tika izslēgta lielinieku pasludinātā augstskola parasti to ignorēja kā īsi pastāvējušu anomāliju. Tās statusu, līdzīgi kā visus lielinieku sociālistiskos pārveidojumus, pamatoti uzskatīja par pretlikumīgu, tādu, kas grauj tiesiskumu un tradīcijas. ${ }^{1}$

Augstskola bija viens no svarīgākajiem jaunās valsts kultūras, ideologijas un noteikti arī politikas izaicinājumiem. Pat nosaukuma meklējumi - vai mācību iestāde saucama par augstskolu vai universitāti - bija liels ideoloǵisks izaicinājums. Vēl ìsi pirms jaunā nacionālā augstskola vēra durvis studentiem, tās izveides komisijas vadītājs filozofs Pauls Dāle 1919. gada 12. septembra sēdē ierosināja to saukt par Latvijas Universitāti. Tomēr pret šādu tagad pašsaprotamu un ierastu nosaukumu izveidojās asa opozīcija, redzamākie tās pārstāvji bija agronoms un nākamais Lauksaimniecības fakultātes dekāns Jānis Bergs un teologs, vēlākais Filologijas un filozofijas fakultātes dekāns Kārlis Kundziņš. Viṇi uzskatīja, ka mācību iestādes nosaukums jāveido pēc iespējas latviskāks, proti, jāsaglabā apzīmējums "augstskola" un jāizvairās no internacionālā vārda "universitāte". Diskusija noslēdzās ar to, ka nolēma jautājumu nodot presei, lai ar tās palīdzību nosaukuma apspriešanā iesaistītu sabiedrību. ${ }^{2}$ Nekāda publiska diskusija gan nesekoja, tā vietā komisijas vairākums vienojās par nosaukumu Latvijas Augstskola. ${ }^{3}$ Bija vajadzīgi vēl trīs gadi, lai akadēmiskā elite atbrīvotos no aizspriedumiem un izškirtos par nosaukumu Latvijas Universitāte, kas saglabājies līdz mūsdienām. 1923. gada 28. martā Latvijas Republikas Saeima apstiprināja augstskolas Satversmi ar jauno nosaukumu. Ar vārdu kombināciju "Latvijas Universitāte" valsts netieši monopolizēja visu augstāko izglītību, neatstājot vietas citām universitāšu tipa augstskolām. Te jāatceras, ka Eiropā vispārpieņemtā prakse bija universitātes saukt pilsētu, nevis valstu 
vārdos. Tālaika Latvijas valstsvīru un akadēmiskās elites skatījumā bija būtiski uzsvērt, ka šì ir jaunās valsts universitāte un, ja radīsies citas, tās būs pakārtotas. Vēlāk LU akadēmiski zinātniskais pārākums izpaudās attieksmē pret jaunajām augstākās izglītības iestādēm, vispirms - Jelgavas Lauksaimniecības akadēmiju, bet jo īpaši cittautiešu veidotajām privātajām augstskolām, piemēram, Rīgas Herdera institūtu un Krievu universitātes zinātṇu institūtu. ${ }^{4}$

Augstskolas izveides tiesiskais pamats bija Pagaidu valdības 1919. gada 2. augusta lēmums par bijušā Rīgas Politehniskā institūta reorganizācijas komisijas izveidi, kas vēlāk pārtapa jaunās nacionālās augstskolas organizācijas komisijā. Sākotnēji process bija pilnīgā Politehnikuma mācībspēku kontrolē. Darba valoda komisijā bija krievu, jo kopš totālās rusifikācijas Krievijas impērijas augstskolās šì bija valoda, kurā saprasties spēja visi. Protokolus rakstīja gan krieviski, gan latviski, privātas sarunas sākotnēji bieži notika vāciski. Komisija sastāvēja no latviešiem un vāciešiem. Latvieši bija k̦īmiķis Pauls Valdens, agronoms Paulis Lejiňš, mašīnbūves inženieris Kārlis Rezevskis un ekonomists Frīdrihs Brēdermanis, kurš pildīja komisijas sekretāra atbildīgos pienākumus, bet vācieši - k̦īmiḳis Voldemārs Fišers (Woldemar Fischer), arhitekts Vilhelms fon Strīks (Wilhelm von Stryk), mehānikas inženieris Pauls fon Denfers (Paul Denffer), ārsts un anatoms Alfreds Zommers (Alfred Sommer), biologs Teodors (Fjodors) fon Buholcs (Theodor Bucholtz), vēsturnieks un geogrāfs Alfreds fon Hedenštrēms (Alfred von Hedenström) un būvinženieris Edgars Jakobijs (Edgar Jakoby). ${ }^{5}$ Kā redzams, stipri jūtams Politehnikuma mantojums - vairākumā bija eksakto zinātṇu pārstāvji, gara zinātṇu pārstāvjus no Tērbatas Universitātes tikpat kā nejuta.

Svarīgi zināt, ka pat latviskas izcelsmes komisijas dalībnieki bija konservatīvi un cieši ieauguši vāciskajā akadēmiskajā vidē, ippaši tas sakāms par P. Valdenu, kurš vadīja tikai pirmās komisijas sēdes (par viṇu sk. arī turpmāk). ${ }^{6}$ Pats P. Valdens atklāti politikā iesaistīties nevēlējās, bet to pašu nevar teikt par viņa kolēgiem. Starp komisijas dalībniekiem bija pavisam nesenajos vācu laikos politiski aktīvas personas. Tā, piemēram, agronomu P. Lejiṇu, vēlāko LU Lauksaimniecības fakultātes dekānu, ar vācu okupācijas varu saistīja viṇa vecākais brālis, pazīstamais ārsts Kārlis Morics Lejiņš. 1917. gada nogalē viņš bija iesaistījies vācu organizētās tautas pārstāvniecības darbā, kuras mērkiis bija izveidot Zemes padomi, kas vēlāk apstiprinātu vāciešu, latviešu un igaunu kopīgu "Baltijas valsts” projektu. Šo Vācijas un vācbaltiešu aristokrātijas politisko iniciatīvu vadīja vācbaltiešu izglītotais sabiedrības virsslānis. Respektablākie pārstāvji nāca no Tērbatas Universitātes un Rīgas Politehnikuma akadēmiskajām aprindām - studentu korporācijām. To vidū īpaši izcēlās korporācija Livonia, kuras biedri Ādolfs Pilars fon Pilhaus (Adolf Konstantin Jakob Pilar von Pilchau) un Heinrihs fon Strīks (Heinrich Eduard Karl von Stryk) Pirmā pasaules kara izskaņā bija nominēti par šīs valsts pagaidu valdības redzamākajiem pārstāvjiem. ${ }^{7}$ Vācu aktivitātēs bija līdzdarbojies arī ekonomists un vēlākais teologs F. Brēdermanis. Savu saistību ar izveidoto Zemes padomi viņš Latvijas proklamēšanas dienā tūlīt pat steidza presē apstrīdēt, kaut gan nenoliedza, ka tās pasākumos piedalījies. ${ }^{8}$ Bez šiem Politehnikuma reorganizācijas komisijas dalībniekiem topošās augstskolas saimē redzamu vietu ieņēma arī no jauktas latviešu un vācu vides nākušais nākamais LU Arhitektūras fakultātes dekāns, profesors un pazīstamais arhitekts Eižens Laube (Eugen Laube), kurš, tobrīd vēl būdams Politehnikuma docents, bija iesaistījies šo vācu plānu realizācijā un kḷuvis par Zemes padomes locekli. ${ }^{9}$ Starp citu, vēlāk F. Brēdermanis un E. Laube vēlreiz kopīgi izmēgénāja laimi 
politikā, startējot Satversmes sapulces vēlēšanās sarakstā no mācītāju un akadēmisko aprindu veidotās Kristīgās nacionālās partijas. ${ }^{10}$ Abu mēgóninājums atkārtoti iesaistīties politikā nevainagojās panākumiem.

Pēc Rīgas pakḷaušanas Pirmā pasaules kara laikā vācu okupācijas vara īpaši cerēja, ka vietējās akadēmiskās aprindas veicinās vācu varas nostiprināšanos. Ar tādu domu jau 1917. gada 8. decembrī Mazajā gildē uz plaši reklamētu sanāksmi bija pulcējušies apmēram 400 akadēmisko aprindu delegāti, lielākoties Rīgas Politehnikuma, bet arī Tērbatas Universitātes pasniedzēji, beidzēji un studenti, lai lūgtu Vācijas valdību uz mūžìgiem laikiem Rīgu un visu Baltiju iekḷaut Vācijas impērijas sastāvā. ${ }^{11}$ Akadēmiskā elite Pirmā pasaules kara gados sevi bija publiski pozicionējusi kā Vācijai lojālu un vācu plānus atbalstošu. Tagad politiskā situācija bija mainījusies, bija jāpielāgojas jaunajai realitātei, dažiem to izdarìt bija viegli, citiem grūti vai pat neiespējami, jo nebija pieņemama K. Ulmaņa Pagaidu valdības politiskā platforma. Pirms Latvijas proklamēšanas piedzīvotās politiskās neveiklības akadēmiskā elite tomēr turpmāk centās aizmirst un publiski vairs necilāt. Tā noteikti bija augstu vērtējama akadēmiski izglìtotas un tolerantas sabiedrības iezīme.

Latvijas Augstskolas izveide jau 1919. gada augusta otrajā pusē nonāca latviešu vairākuma rokās. Konservatīvo vāciešu īpatsvars reorganizācijas komisijā mazinājās. 1919. gada septembrī tajā līdzdarbojās virkne jaunpienācēju, to starpā turpmākajos gados pazīstamie Universitātes mācībspēki inženieris Pēteris Nomals, arhitekti E. Laube un Ernests Štālbergs, k̦īmiķis Mārtinšs Prīmanis, teologs K. Kundziņš u. c. ${ }^{12}$ Daudzi bija politiski aktīvi, viņus iedvesmoja iesaiste jaunās nacionālās augstskolas izveidē. Augstskolas tapšanas apstākḷi gan vairāk rāda pārmantojamību, nevis jaunā radīšanu. Jaunais slēpās idejā par nacionālo augstskolu, kur gatavotu valstij noderīgus speciālistus un mācības notiktu latviski, bet tās praktiskais izpildījums balstījās uz veco augstākās izglītības tradīciju. Līdztekus akadēmiski zinātniskajam mantojumam izteikta pārmantojamība no Rīgas Politehnikuma laikiem bija vērojama administrācijā un lietvedībā. Te faktiski nenotika nekādas izmaiņas. Kad 28. septembrī Latvijas Augstskola oficiāli vēra durvis, joprojām ienācēju augstskolā sagaidīja tas pats impozantais, krāšņā uniformā tērptais šveicars, imperatora jātnieku pulka gvardes bijušais kavalērists Pēteris Miḳelsons, kurš te bija strādājis kopš 1900. gada un turpināja šo darbu līdz pat 1935. gadam. ${ }^{13}$

Augstskolas kanceleja jeb sekretariāts un tā personālsastāvs tāpat bija maz mainījies. Sekretariātu vadīja latvietis Aleksandrs Valdmanis, kurš Politehnikuma kancelejā bija sācis strādāt jau 1889. gadā ${ }^{14}$ (turpat strādāja arī viṇa sieva). Vinšs turpināja vadìt sekretariātu gan Pirmā pasaules kara laikā, gan P. Stučkas valdīšanas mēnešos 1919. gadā, ${ }^{15}$ gan Latvijas Republikas un okupācijas laikā, līdz pat emigrācijai uz Vāciju 1944. gadā, kad bija sasniedzis cienījamu 70 gadu vecumu. Apbrīnojamās amata uzticības dēḷ (A. Valdmanis burtiski esot dzīvojis augstskolā) viņš bija tik pieredzes bagāts administrācijas jautājumos, ka vinuu respektēja visas varas un vecākās paaudzes akadēmiskais personāls. Turklāt A. Valdmanis konsekventi norobežojās no politikas, tādēl represīvās varas vin̄ā nesaredzēja pretinieku. Universitātes vadība vēlāk ierosināja A. Valdmanim piešķirt Triju Zvaigžņu ordeni par LU administrēšanu kara apstākḷos 1919. gada rudenī, tomēr, iespējams, tieši A. Valdmaņa politiskā distancētība un vāciskais tēls bija cēlonis, kādēl viņš apbalvojumu tā arī nesaṇēma. ${ }^{16} \mathrm{~K}$. Ulmaṇa autoritārisma gados LU iekšienē gan bija jūtama zināma kurnēšana par rektorāta (sekretariāta) un iestādes "pelēkā kardināla” A. Valdmaṇa škiietamo vāciskumu, kurš 
gímenē ar sievu sarunājies vāciski un, nen,emot vērā labo atalgojumu, pilnīgi nemaz nav pievērsies iestādes reprezentācijai uz ārieni. Darbu augstskolā A. Valdmanis beidza tikai līdz ar vācu okupācijas karaspēka un civilās pārvaldes atkāpšanos no Rīgas 1944. gada oktobrī. ${ }^{17}$ Zīmīgi un pamācoši ir tas, ka sekretariāts pildīja visas (!) augstskolas administrācijas funkcijas. Studentu skaits LU salīdzinājumā ar Politehnikuma laikiem bija pieaudzis, bet sekretariāta darbinieku skaits pat samazinājies. Kā augstskolas vadībai daudzkārt ziņoja sekretariāta darbinieki, viṇi tikuši galā ar pienākumiem, tikai pateicoties ilggadējai pieredzei. Situācijas ilustrācijai 1930. gadā LU bija 8570 studentu, bet sekretariātā - tikai 14 darbinieki. Tiešām apbrīnojama darba organizētība, kas nav iedomājama mūsdienās. Toreiz LU sekretariāts veica visu darbu studentu lietās, kā arī LU Padomes, dekānu padomes, rektorāta un citās lietās. Protams, sekretariāts regulāri sūdzējās par pārslodzi un prasīja darbinieku skaitu palielināt vismaz par 3-4 darbiniekiem. ${ }^{18}$

Līdzịgi kā valstī kopumā tās pastāvēšanas pirmajos gados, arī augstskolas darbības priekšnoteikums bija finansējums. Akadēmiskajās aprindās vispārzināms bija Rīgas Politehniskā institūta saimnieciskās veiksmes stāsts. Pirms darbības apturēšanas institūtam bija nauda, obligācijas, vērtspapīri un citas vērtības 869262,50 rublıu apmērā. ${ }^{19}$ Savukārt visa kapitāla lielums, ieskaitot nekustamo īpašumu, bija 2571 058,29 rubḷi - visnotal iespaidīga summa. ${ }^{20}$ Sākotnēji bija cerības, ka līdzekl̦us izdosies atgūt un tas būs "starta kapitāls" augstskolai. Drīz nacionālās augstskolas veidotāji bija spiesti piedzīvot smagu vilšanos, jo prāvie finanšu līdzekḷi kara un juku laikos bija zuduši. Daudzie stipendiju fondi un dāvinājumi bija jāpasludina par slēgtiem, jo līdzekḷi tajos nebija atgūstami. ${ }^{21}$ Tādēl 1919.-1920. gadā finanšu resursu trūkuma dēl personālā pat bija jūtama bezcerīga nolemtība. Pamatu izaugsmei saredzēja jaunatnes vēlmē studēt (proti, ar to saistītajās studiju maksās), kas kḷuva par raksturīgu tālaika sabiedrības iezīmi.

Visas varas, kas lielajā juku gadā 1919. gadā - valdīja Rīgā (lielinieki, vācieši utt.), bija plānojušas izsludināt studentu uzṇemšanu. Tai bija jānotiek septembrī. K. Ulmaņa Pagaidu valdība šo mērḳi turpināja īstenot. Pieprasījums pēc augstākās izglītības bija liels, prasība par latviešu inteliǵences vairošanu bija pašsaprotama, un valdīja pārliecība, ka tagad augstskolas durvis visiem nacionālajiem censoniem būs plaši atvērtas. Laika organizācijai bija pavisam maz, turklāt neviens nebija pilnīgi pārliecināts par militārpolitisko stabilitāti un valsts izredzēm - turpinājās brīvības cīṇas. Vispirms bija jāizlemj par kritērijiem studētgribētājiem. Kopumā saglabājās daudz iezīmju, kas piemita Krievijas impērijas laika kārtībai. Pirmais augstskolas rektors Ernests Felsbergs cara laika augstākās izglītības mantojuma iznīdēšanu studiju procesa organizēšanā pat pasludināja par vienu no svarīgākajiem darbības uzdevumiem. Uz Krievijas parauga balstītais obligāto priekšmetu lielais skaits, nepieciešamība pelnīt naudu studiju maksai, savā jomā vienīgā topošā speciālista atkarība no mazāk zinošiem profesoriem bija impērijas mantojums, ko viṇš vēlējās aizstāt ar Rietumeiropas liberālo augstākās izglītības pieredzi. ${ }^{22}$ Šādu uzdevumu varēja īstenot tikai ar atbilstošu akadēmisko personālu, bet tieši mācībspēku trūkums bija viena no galvenajām problēmām. Pēc lielinieku padzī̌anas no Rīgas 1919. gada vasarā augstskolas administrācijas pārstāvji konstatēja, ka par pasniedzējiem var noalgot tikai 14 štata pasniedzējus. Tie bija inženierisǵeologs Alvils Buholcs (Alwill Buchholtz), agronoms Vilhelms Burzians (Wilhelm Bursian), inženieris Oskars Hābermanis (Oskar Habermann), biologs Ernsts Hekels (Ernst Häckel), aizvēsturnieks un etnologs 
Fricis Henšels (Fritz Haensell), vēsturnieks un ġeogrāfs A. fon Hedenštrēms, inženieris Karls Heincs (Karl Heintz), arhitekts E. Laube, filologs Oskars Māzings jeb Maziņš (Oscar Masing), ${ }^{23}$ jurists Karls Šillings (Carl Schilling), statistiķis Burhards fon Šrenks (Burchard von Schrenck), filologs Alberts Fogts (Albert Vogt), arhitekts Eduards Veiss (Eduard Weiß), ${ }^{24}$ filologs Rūdolfs Cimmermanis (Rudolf Zimmermann), ${ }^{25}$ pieci ārštatnieki - kīmikis Maksimiliāns fon Glāzenaps (Maximilian von Glasenapp), veterinārmedikis Kārlis Kangro (Carl Kangro), valsts zinību speciālists Vilhelms Klumbergs (Wilhelm Klumberg), ${ }^{26}$ inženieris Georgs Nolteins (Georg Noltein), inženieris Voldemārs Vencelidess (Woldemar Wencelides) ${ }^{27}$ un seši asistenti. ${ }^{28}$ Protams, tas bija pieticīgs akadēmiskā personāla štats, turklāt absolūta vācu dominante, tomēr tieši šie cilvēki pelnījuši atzinību, jo vairums no viniiem kḷuva par pirmajiem Latvijas Augstskolas akadēmiskā personāla pārstāvjiem.

Svarīgs uzdevums bija atgūt pasaulē izklīdušos Latvijai piederīgos mācībspēkus un noteikt prasības akadēmiskajiem amatiem. Īpaši tas attiecās uz latviešiem. Prasības pasniedzēja amatam bieži bija visai pieticīgas, tas skaidrojams ar akadēmiskā personāla katastrofālo trūkumu. ${ }^{29}$ Sākums bija grūts un haotisks, bet jau 1921. gadā bija nokomplektēts mācībspēku pamatsastāvs - strādāja 48 profesori, 94 docenti, devin̄i privātdocenti, 19 lektori, 42 asistenti, bija izveidota un darbu sākusi centrālā bibliotēka. ${ }^{30}$ Turpmāk akadēmiskā personāla skaits turpināja augt, tā, piemēram, 1933. gadā jau bija 94 profesori un 160 asistenti. ${ }^{31}$

Līdzịgi kā mūsdienās, aktuāls jautājums bija motivējoša atalgojuma izmaksa, lai valsts augstskolai piesaistītu trūkstošo akadēmisko personālu. 1919. gada 9. septembra sēdē augstskolas veidotāji nolēma, ka sākotnēji noteiktā profesoru alga jāpalielina no 900 rubḷiem mēnesī lìdz
1200 rubḷiem, jo mācībspēku ieskatā algas lielums nebija konkurētspējīgs. Te gan jāteic, ka arī 1200 rublu lielais atalgojums pēckara inflācijas apstākḷıs bija pieticīgs. Sākotnēji augsti un reāli neizpildāmi bija arī pasniedzēju slodzes jeb nodarbinātības kritēriji. Tā, piemēram, bija noteikts, ka pilnas algas saṇemšanai jānovada sešas stundas nedēḷā - lekcijas vai praktiskās nodarbības. Profesoriem noteica algu par sešām stundām nedēḷā līdz 1200 rubḷiem mēnesī un par katru virsstundu 50 rubḷus nedēlāa . Docentiem paredzēja maksāt $3 / 4$ no profesoru algas, savukārt rektoram pie pasniedzēja algas nolēma papildus maksāt 600 rubḷu mēnesī utt. ${ }^{32}$

Vairākums augstskolas veidotāju ñēma vērā valsts smago saimniecisko realitāti un priekšstatos par atalgojumu bija pieticīgi. Tā, piemēram, K. Kundziņš, J. Bergs un S. Paegle pat bija pārliecināti, ka augstskolai jānodrošina pasniedzēji tādā apmērā, lai papildu darbs citviet nebūtu jāstrādā. İpaši to attiecināja uz papildu darbu valsts sektorā. Tādēl, nolēma, ka valsts dienestā strādājošie var augstskolā saṇemt tikai pusi algas. ${ }^{33}$ Ievērojami mazākas bija augstskolas sekretariāta darbinieku algas - vinuu pārziņā pēc darba uzsākšanas nonāca kopējā lietvedība, administrācija, visi nepabeigtie ar Politehnikuma pārņemšanu saistītie jautājumi utt. Augstskolas sekretariāta vadītājs A. Valdmanis 1920. gada augustā saṇēma 225 rubḷus mēnesī, vēl algoja tikai mašīnnrakstītāju un kurjeru. ${ }^{34}$

Lai saprastu, kāds bija augstskolas algu salīdzinošais apmērs, labs palīgs ir tālaika pārtikas produktu cenas. 1920. gada vasarā Rīgā viena mārcina $(0,453 \mathrm{~kg})$ rupjmaizes brīvajā tirgū bez pārtikas kartītes maksāja ap 2,5 rubliiem, mārciṇa cūkas spek̦a vai kartupeḷu - ap 5-6 rubl̦iem, mārciṇa kviešu miltu - ap 12 rubliem, mārcina sviesta - ap 27-30 rubliiem, bet importprece cukurs - pat vairākas reizes dārgāk par sviestu utt. ${ }^{35}$ Vēl jānem vērā, ka tobrīd 
Latvijā bija uzbangojusi pēckara pārvērtību izsauktā inflācija, pārtikas cenas kopš 1919. gada nogales bija palielinājušās vismaz divreiz. Tādējādi augstskolas samaksa drīzāk uzskatāma nevis par atalgojumu, bet gan darbu "par vēdera tiesu". Cenas laukos bija zemākas, bet rīdziniekiem tas neko nenozīmēja, jo tālāki braucieni bija retums. Droši var teikt, ka lielā mērā augstskolas izveide balstījās uz tās veidotāju entuziasmu un pašuzupurēšanos, līdzīgi kā tas notika arī Latvijas valsts izveides darbā.

Lielais pasniedzejju darba stundu skaits nedēẹā un ar to saistītā atalgojuma apjoms tika asi kritizēts jau kopš 1919.1920. gada. Visasāk to kritizēja pasniedzēji ar Eiropas augstskolu pieredzi. Sevišḳi izcēlās no Vācijas atbraukušais pazīstamais latviešu tautsaimniecības profesors un vēlākais politikịis Kārlis Balodis, kurš 1919. gada 23. septembra sēdē uzsvēra, ka ārzemēs profesoram prasa tikai divas lekciju stundas un vienu semināra stundu nedēḷā, tādēḷ arī Latvijā stundu skaita minimums būtu ievērojami pazemināms. ${ }^{36}$
Ilustrācijai ieskats Filolog̣ijas un filozofijas fakultātes darbinieku noslodzē 1920. gadā, kas, piemēram, bija krietni mazāka nekā Mehānikas fakultātē, kur bija daudz praktisko darbu (apm. 16 stundas nedēlāa). ${ }^{37}$

Jau tā samilzušajai atalgojuma problēmai un finanšu līdzekḷu nepietiekamībai kopš 1919. gada otrās puses klāt nāca bijušo Politehnikuma pasniedzēju, darbinieku, atraitņu vai citu pēcteču prasības par pabalstu un pensiju izmaksu. Bieži augstskolas veidotāji saņēma emocionālus iesniegumus par postu un trūkumu, kādā dzīvojušas redzamu universitātes profesoru atraitnes vai citi pēcteči. Ĺoti aktīvi pieprasīt Politehnikuma kādreiz pieškirtās privātās pensijas sāka mantinieki, atraitnes un bērni no Vācijas. Visbiežāk tie bija vācbaltieši, kas bija devušies emigrācijā pēc lielajām politiskajām pārvērtībām. Latvijas Augstskolai kā saistību pārnēemējai jau tā smagajā kara un pēckara laika finanšu situācijā pensiju izmaksa uzlika smagu slogu. 1920. gada iesākumā augstskolas

Tabula

Pamatdarbā Latvijas Augstskolā strādājošo pasniedzēju darba apjoms nedēḷā (noslodze) Filoloǵijas un filozofijas fakultātē 1920. gada rudens semestrī ${ }^{38}$

\begin{tabular}{|c|c|c|c|}
\hline Amats, vārds, uzvārds & $\begin{array}{l}\text { Vadito } \\
\text { nodarbỉbu } \\
\text { valoda }\end{array}$ & $\begin{array}{l}\text { Lekciju un/vai semināru nosaukums, ilgums } \\
\text { stundās }\end{array}$ & $\begin{array}{l}\text { Kopā } \\
\text { stundas } \\
\text { nedēḷā }\end{array}$ \\
\hline Doc. Leonīds Arbuzovs & Krievu & $\begin{array}{l}\text { Viduslaiku vēsture (4 st.), Vēstures seminārs } \\
\text { (2 st.) }\end{array}$ & 6 \\
\hline $\begin{array}{l}\text { Prof. (ar Mg. grādu) } \\
\text { Ernests Felsbergs }\end{array}$ & Latviešu & $\begin{array}{l}\text { Mākslas vēsture (2 st.), Ievads klasiskajā } \\
\text { filologijijā ( } 2 \text { st.), Griekijas vēsture (2 st.), Griekiu } \\
\text { autori (2 st.) }\end{array}$ & 8 \\
\hline Doc. Arnolds Spekke & Latviešu & $\begin{array}{l}\text { Spāņu literatūras vēsture (2 st.), Ievads romāṇu } \\
\text { filoloğijā ( } 2 \text { st.), Vakareiropas literatūras vēsture } \\
\text { (2 st.). }\end{array}$ & 6 \\
\hline Doc. Pēteris Zālīte & Latviešu & $\begin{array}{l}\text { Filozofijas vēsture (3 st.), Filozofijas seminārs } \\
\text { (2 st.) }\end{array}$ & 5 \\
\hline Prof. Jānis Endzelīns & Latviešu & $\begin{array}{l}\text { Latviešu valoda ( } 3 \text { st.), Slāvu valodas } \\
\text { salīdzinošais kurss ( } 3 \text { st.), Ģermāṇu pirmvaloda } \\
\text { (2 st.) }\end{array}$ & 8 \\
\hline
\end{tabular}


vadība gan apṇēmās maksāt līdz šim pieškirtās pensijas pensionētajiem darbiniekiem un atraitnēm samazinātā apmērā, ${ }^{39}$ tomēr drīz noteica, ka pensiju izmaksu regulēs speciāls likums. ${ }^{40}$

Apmēram divu gadu laikā pēc Neatkarības kara beigām atalgojuma sistēmu augstskolā izdevās sakārtot un padarīt taisnīgu un saprotamu. Tā, piemēram, 1922. gada rudenī rektora atalgojums pielīdzināts ministra biedra atalgojumam, profesori pielīdzināti 1. ierēdṇu kategorijai, kurus iecel Ministru kabinets, docenti - 4. kategorijai, kurus iecel resora priekšnieks utt., dekāni san̄ēma $30 \%$ no profesora algas plus 10 rubḷus par katru fakultātes studentu, fakultātes sekretārs - 25\% no profesora algas plus 2,5 rublius par katru studentu utt. ${ }^{41}$ Šì sistēma, kur augstskolas akadēmiskais personāls tika pielīdzināts valsts ierēdņiem, lāava vēlāk piešķirt valsts garantēto vecuma pensiju tiem, kas augstskolā vai citā valsts ierēdnim līdzvērtīgā amatā bija nostrādājuši vismaz 20 gadus. Lìdz okupācijai valsts garantētās vecuma pensijas attiecās uz visai šauru Latvijas iedzīvotāju daḷu, tādēḷ šāda iedzīvotāju grupa bija privilegèta.

Nesamērīgi augstu noteiktās pasniedzēju slodžu prasības 20. gados LU pakāpeniski samazināja un atalgojumu palielināja. Tas bija cieši saistīts ar vispārējo ekonomiskās situācijas uzlabošanos. Augstskola sāka izskaust mācībspēku daudzus gadus piekopto paralēlo nodarbinātību. Universitātes Padome 1925. gada 4. februārī pieņēma lēmumu, ka štata vieta augstskolā nav savienojama ar citu štata vietu valsts vai privātā dienestā uz pilnu darba laiku. Ar augstskolas Padomes piekrišanu bija atl̦auta blakus nodarbošanās, ja tā nav valsts darbs un ir saistīta ar mācībspēka specialitāti un netraucē darbam Universitātē. ${ }^{42}$

LU pasniedzēju personīgās lietas arhīvā liecina, ka jau 20. gadu beigās un 30. gadu sākumā profesori tomēr saṇēma Latvijas apstākḷiem l, loti labu atalgojumu. Tā, piemēram, Arhitektūras fakultātes dekāns, profesors un plaši pazīstamais arhitekts E. Laube par 1928. gadu bija atalgots ar 10 461,74 latiem (mēnesī vidēji 871 Ls), bet par 1930. gadu saṇēma 9461,84 Ls (mēnesī vidēji 788 Ls). ${ }^{43}$ Šāds atalgojums l̦āva ne tikai pilnvērtīgi pārtikt, bet arī iegādāties tālaika luksuspreces (gleznas, vērtslietas, radioaparātus, pat automobilus). Tā kā atalgojums bija saistîts arī ar valstī noteiktām valsts amatpersonu algu kategorijām, mācībspēki saṇēma līdzīgu atalgojumu, tas nemēdza atškirirties atseviškāa fakultātēs, un to nekādā veidā neietekmēja pasniedzēja tautība vai pavalstniecība. Tā, piemēram, Vācijas pavalstnieks, vācietis un LU ilggadējs teologijas profesors Imanuels Bencingers (Immanuel Benzinger) san̄ēma algu pēc 1. amatu grupas, kas 1930. gadā bija kopā 10368 Ls (mēnesī vidēji 864 Ls). ${ }^{44}$ Savukārt vēstures profesors vācbaltietis Leonīds Arbuzovs (Leonid Hans Nikolaus Arbusow) 1930. gadā saṇēma 8578,56 Ls (mēnesī vidēji 714 Ls). ${ }^{45}$ Turklāt jāatzīmē, L. Arbuzovs nebija pārlieku centīgs lektors, lekcijas 20. gadu nogalē joprojām lasīja krieviski, semestrī mēdza noturēt tikai vienu vai maksimāli divus nodarbību kursus un atseviškos gados kā zinātnisko sasniegumu norādīja tikai mazus šķirkḷus leksikonos vai dažas lapas apkopojošās grāmatās, kas izdotas ārpus Latvijas, toties devās zinātniskos komandējumos un savāca Latvijas vēsturei noderīgu materiālu Vatikāna arhīvā. ${ }^{46}$ Pasniedzēju atalgojums parasti spēja pilnībā nodrošināt viṇu gimenes. Profesoru atalgojums mēnesī bija pat 6-8 reizes lielāks nekā parastam rūpnīcas strādniekam. Profesoru un arī docentu sievas tādēḷ varēja nestrādāt algotu darbu - tā bija visai plaša parādība 30. gados. Solīdais atalgojums bija apliecinājums, ka LU augstu novērtē katru mācībspēku un viṇa sniegumu pat tajos gadījumos, kad mācībspēks vadīja tikai vienu lekciju kursu semestrī. 
Arī paši pasniedzēji bija lojāli savai darbavietai, nemēdza to pamest un strādāja l̦oti godprātīgi.

Liels saimniecisks ieguvums LU bija arhitekta un uzn̄ēmēja Kristapa Morberga pēcnāves novēlējums 1928. gadā. K. Morbergs novēlēja Universitātei astonuus namīpašumus Rīgas centrā un Jūrmalā, kā arī finanšu resursus. Latvijas apstākḷiem milzīgā dāvinājuma pārṇemšana un apsaimniekošana lika LU apgūt jaunas finansiālas un saimnieciskas ieman,as, kādas agrāk tai nebija vajadzīgas. Filantropa dāvināto īpašumu pārṇemšanā aktīvi iesaistījās viṇa atraitne vāciete Auguste Morberga, dzimusi Hartmane. Savukārt tūlīt pēc dāvinājuma saņemšanas uzradās vairāki K. Morberga radinieki un ǵimenes kalpotāji, kas lūdza ikmēneša pensijas no K. Morberga dāvinājuma (fonda). ${ }^{47}$

Saskaṇā ar mecenāta novēlējumu LU rīcībā nonāca arī prestižais viesnīcas "Roma" nams (saukta arī Hotel de Rome, Otrā pasaules kara laikā nams nodega, tagad tā vietā ir viesnīca "Rìga"). Tas uzskatāms par nozīmīgāko novēlējuma sastāvdaḷ. LU nolēma to iznomāt. 1930.-1931. gada mijā LU rīkoja sacensību (konkursu) par "Romas" viesnīcas un restorāna nomu. Vienlaicīgi ar nomnieka izvēli LU uzsāka arī vērienīgu viesnīcas pārbūvi. Būvdarbu kontroli uzṇēmās arhitekts, ilggadējais Arhitektūras fakultātes dekāns profesors E. Laube. ${ }^{48}$ Viesnīcas pārbūve sakrita ar vispasaules ekonomiskās depresijas periodu, tādēḷ projekta īstenošana ieilga, uz brīdi kḷuva pat bezcerīga. Krīzes iespaidā projekta finansēšanai nevarēja piekḷūt lielā filantropa uzkrātajam kapitālam. Kapitāls glabājās dažādās bankās, un visām bija radušās finanšu grūtības, tostarp sabrukumu piedzīvoja "Unionbanka" un dažādas savstarpējās kreditēšanas iestādes, kur mecenāts kādreiz bija ieguldījis naudu. Tādējādi apdraudēta bija visa K. Morberga novēlējuma finanšu līdzekḷu daḷa. Rīgas vācu prese, kas bija īpaši ieinteresēta viesnīcas jautājumā (viesnīcas un restorāni bija vācisks bizness, tāpēc arī "Romas" nomnieki Jirgensoni, būdami latvieši, saglabāja vācisku uzvārda transkripciju, lai turpinātu vēl pirms Pirmā pasaules kara popularitāti iemantojušā uzṇēmuma zīmola slavu), kritizēja LU par to, ka tā savu kapitālu nav glabājusi drošākā vietā, piemēram, Latvijas Bankā, ${ }^{49}$ bet augstskola attaisnojās, ka pats novēlētājs naudu ieguldījis šādos finanšu institūtos. ${ }^{50}$

Viesnīcas atklāšana pēc pārbūves 1932. gada 9. septembrī kḷuva par svarīgāko notikumu augstskolas dzīvē 1932. gadā un droši vien par nozīmīgāko saimniecisko notikumu visā tās pastāvēšanas vēsturē. Tās atklāšanu vadīja LU rektors Mārtiņš Bīmanis, piedalījās Valsts prezidents Alberts Kviesis, Ministru prezidents Margers Skujenieks, valdības ministri, ārvalstu diplomāti un citi sabiedrībā redzami l̦audis. Šī neapšaubāmi tobrīd bija lielākā, modernākā un prestižākā viesnīca valstī, līdz ar to tās atklāšana bija ievērojams notikums visas valsts dzīvē. Modernizācija un pārbūve skāra visas nama telpas, îpaši nozīmīga bija laikmetam atbilstošu vannas istabu izbūve viesnīcas 67 numuriņos, kā arī pirmā stāva restorāna Otto Schwarz un slavenā pagrabstāva restorāna-kroga "Romas pagrabs" (Romkeller) pārbūve. Viesnīcas numuriņu mēbeles un interjera priekšmeti gan vēl bija saglabājušies no iepriekšējiem laikiem un kādam varēja šḳist nolietoti vai bezgaumīgi. Liela nozìme "Romas" viesnīcas un restorānu spožajā slavā pirms un pēc renovācijas bija ši ğimenes uzṇēmuma ilggadējai valdes priekšsēdei Dorei Jirgensonei, kura, kā viesnīcas atklāšanas brīdī rakstỉja Rīgas vācu prese, bija lieluzņēmuma "smadzenes" un vienlaicīgi gastronomiski skolotā "dvēsele". ${ }^{51}$ Latviešu preses izdevumi savukārt cerīgi piebilda, ka restorāna saimnieki solījuši cenas turēt "piemērotas krīzes laikam". ${ }^{52}$ Jau pēc dažiem gadiem par viesnīcu teica, ka tā esot 
viena no labākajām Eiropā, līdzīgi arī tās restorāni, kas izceḷoties ar priekšzīmīgiem ēdieniem, grezno arhitektūru un interjeru franču karal̦a Ludviga XVI stilā. ${ }^{53}$ Tik tiešām, gan viesnīca, gan tās restorāni kḷuva par vietu, kur regulāri pulcējās valdības un dažādu organizāciju pārstāvji, notika diplomātiskas sarunas un vienošanās par līgumiem. Reizēm pat škita, ka "Romas" telpas monopolizējušas šo jomu, un, protams, LU varēja patiesi lepoties ar veiksmīgo saimniecisko darbību. Bija skaidri redzams, ka ienākumi par "Romas" viesnīcas apsaimniekošanu ḷauj vēl vairāk uzlabot atalgojumu Universitātē.

Svarīgs darījums LU notika 1940. gadā, līdzīgi kā viesnīcas "Roma” gadījumā, arī tam bija tālejoša nozīme augstskolas finanšu situācijas uzlabošanā. LU un K. Morberga fonds nolēma no Latvijas Kredītbankas iegādāties vācbaltiešu izceḷotāju atstāto viesnīcu Metropol (arī "Metropole", tagad viesnīca Astor), tādējādi kara apstākḷos ieguldot apdraudēto valūtu vērtīgā nekustamajā īpašumā. 1940. gada 18. martā LU un K. Morberga fonds nosūtīja attiecīgu pirkuma piedāvājumu Latvijas Kredītbankai, kuras pārzin̄ā bija nonākuši vācu īpašumi. 12. jūnijā, īsi pirms Latvijas okupācijas, Latvijas Kredītbankas direktors Andrejs Bērziņš deva savu piekrišanu darījumam. ${ }^{54}$ Ieñēmumus no viesnīcas apsaimniekošanas bija paredzēts izmaksāt mazturīgo un centīgo studentu stipendijām. ${ }^{55}$ Tāpat kā viesnīcu "Roma", arī Metropol LU vadītais K. Morberga novēlējuma fonds nodeva nomā A/S Ch. Jürgenson - Otto Schwarz, tikai šoreiz bez konkursa. ${ }^{56}$ Līdzšinējā veiksmīgā sadarbība un uzṇēmuma prestižs Eiropas mērogā padarīja alternatīvu meklēšanu par bezjēdzīgu.

Latvijas Augstskolas attīstība piedzīvoja līdzīgu saimniecisku izaugsmi, burtiski atspoguloja aktuālo valsts saimniecisko situāciju, ko diktēja gan pašmāju, gan starptautiskā situācija. Tādējādi augstskolas attīstībā labi vērojams gan pēckara saimnieciskās un finanšu krīzes iespaids, gan 20. gadu izaugsme, 30. gadu sākuma ekonomiskās krīzes iespaids un saimnieciska atkopšanās turpmākajos gados.

\section{Demokrātijas perioda sasniegumi un problēmas}

Tomēr daudz uzskatāmākas, pat sistemātiskas ir politiskās paralēles, kas sākas ar pašiem valsts pirmsākumiem. Baltijas Tehniskās augstskolas, vēlākie Latvijas Augstskolas studenti bija blakus latviešu politikiiem Tautas padomē, kad tā proklamēja Latvijas Republiku. Divas Rīgas latviešu studentu korporācijas "Selonija" un "Talavija" rūpējās par drošību Latvijas proklamēšanas laikā Rīgas Otrajā teātrī (tagad Nacionālais teātris). Savukārt nākamajā dienā, 1918. gada 19. novembrī, arhitektūras students, vēlākais brīvības cīnu dalībnieks, LU Filologijas un filozofijas fakultātes filozofijas absolvents ${ }^{57}$ un "Pērkonkrusta" organizācijas vadītājs, "Selonijas" biedrs Gustavs Celmiňš kopā ar savu korporācijas biedru Nikolaju Grundmani un citiem savas korporācijas biedriem pie tagadējās Latvijas Universitātes galvenās ēkas ieejas durvīm izkāra divus karogus, šūtus no teātrī izmantotā sarkanbaltsarkanā drapējuma. Tā bija pirmā reize, kad neatkarīgās valsts vēsturē pie kādas oficiālas iestādes vairākas dienas plīvoja Latvijas karogs. ${ }^{58}$ Dienu pēc Latvijas neatkarības pasludināšanas, vācu okupācijas karaspēkam vēl atrodoties Rīgā, G. Celmiņa vadībā no postamenta gāza arī vācu varas jaunizveidoto un latviešu nīsto vācu militārisma un spēka simbolu - no koka veidoto vācu "landšturma" (zemessardzes) karavīra monumentu, kas atradās laukumā pie tagadējās Rīgas apgabaltiesas. Studenti apsējuši virvi ap skulptūru, vilkuši to pa Rīgas ielām un kādā pagalmā sadedzinājuši, 
paturot koka šautenes galu kā trofeju, tādējādi Rīga un jaunā Latvija bija atbrīvojusies no okupācijas varas simbola, par kuru studentu aprindās klīdis ironisks skaitāmpantiņš: "Kas tika sists un nenosists, to tagad sargā landšturmists." ${ }^{59}$ Nedrīkst aizmirst arī par Rīgas studentu lielo atbalstu politiskām pārvērtībām 1918.-1920. gadā. Tā, piemēram, visas vācu studentu korporācijas jau 1918. gada novembra pirmajā pusē aktīvi iesaistījās vietējā karaspēka - zemessardzes (landesvēra) veidošanā un vēlāk Latvijas karaspēka sastāvā Neatkarības kara laikā (1918-1920) dedzīgi cīnījās ar lielinieku sarkano armiju. Līdzīgi arī latviešu studentu korporāciju veidotā Atsevišķā studentu rota bija viena no pirmajām Latvijas karaspēka vienībām un pašaizliedzīgi piedalījās cīṇās ar Latvijas pretiniekiem. Tās komandieris Artūrs Galindoms pēc LU Arhitektūras fakultātes beigšanas kḷuva pazīstams kā Baltijas valstīs pirmā modernā iepirkšanās centra - Armijas ekonomiskā veikala (tagad "Galerija Centrs") - un Latvijas Kara muzeja projektu autors.

Studenti un akadēmiskā vide tolaik bija intelektuālie līderi, kas pārējai sabiedrībai rādīja vajadzīgo politiskās attīstības virzienu. Nereti šis virziens ieņēma izteikti nacionālu nokrāsu un radīja domstarpības starp latvisko un vācisko. Tā bija raksturīga perioda iezīme, bet pēc brīvības cīnu beigām vairs nekad nenoveda pie bruṇotas sadursmes.

Politiskā attīstība savu zīmogu atstāja arī uz augstskolas vadību. Spilgts piemērs ir P. Valdens, kam nenoliedzami bija liela pieredze Rīgas Politehniskā institūta direktora amatā (1902-1906) un lieli nopelni kīmijā. Kara un juku gados pat bija grūti iedomāties citu augstskolas vadītāju vina vietā. Pat lielinieku režìms P. Valdenu 1919. gada 7. maijā iecēla par augstskolas vadītāju, un viņš paguva izpelnīties padomju preses uzslavas kā Latvijas Augstskolas "nopietnākais zinātnieks". ${ }^{60}$
Augstskolas vadītāja amatā viṇš palika arī vēlāk, kad A. Niedras Latvijas Pagaidu valdības provāciskie spēki 1919. gada 22. maijā lieliniekus bija padzinuši no Rīgas un atjaunoja vācu laiku Tehnisko augstskolu, bet 1919. gada 2. augustā K. Ulmaņa Pagaidu valdība viņu apstiprināja par Bijušā Rīgas Politehniskā institūta reorganizācijas komisijas vadītāju un par Latvijas Augstskolas faktisko pagaidu vadītāju, vēl vairāk - 4. augustā iecēla pat par Izglìtības ministrijas Zinātnes un augstskolas departamenta direktoru. ${ }^{61}$ 1919. gada 26. novembrī bijušā Rīgas Politehniskā institūta reorganizācijas komisijas (kopš 16. septembra - Latvijas Augstskolas organizācijas komisijas) priekšsēdētāja amatu no P. Valdena pārnēèma izglītības ministra Kārḷa Kasparsona ieceltais filozofs P. Dāle, kurš šo amatu pildīja līdz 1921. gada 1. jūlijam. ${ }^{62}$ Savukārt no Zinātnes un augstskolas departamenta direktora amata P. Valdenu valdība atbrīvoja tikai 1919. gada 29. decembrī, ${ }^{63}$ kaut gan faktiski visus Latvijā ieņemtos amatus viņš pārstāja pildìt jau 1919. gada 16. augustā, kad komandējuma aizsegā bija devies uz Vāciju pie sievas; uz Latvijas Augstskolas atvēršanu 28. septembrī viņš neieradās ${ }^{64}$ un drīz sāka strādāt Rostokas Universitātē.

Tā kā P. Valdens bija audzis un skolojies vāciskā vidē un ar to cieši saradis, pret savu, augstskolas un visas valsts latviskumu viņš bija vienaldzīgs. P. Valdena uzskati sakrita gan ar tradicionālo Baltijas vācu eliti, gan ar internacionāli noskaņotajiem latviešu lieliniekiem, kuri pret latvisku augstskolu izturējās skeptiski. Saskaņā ar laikabiedru liecībām viņš apšaubījis mazu nāciju kultūras pastāvēšanu un ironizējis par latviskas augstskolas iespēju, bieži pieminējis, ka kīmijā latviski rakstīt un lasīt nav iespējams. ${ }^{65}$ Zīmīgi arī, ka vinšs pārtrauca darbu jaunveidojamā augstskolā brīdī, kad Latvijas Republiku sāka apdraudēt Pāvela Bermonta-Avalova tā sauktā 
Rietumu brīvprātīgo armija (Zapadnaja dobrovol'cheska armija, Die Westrussische Befreiungsarmee) Kurzemē. Tajā laikā viens no pirmajiem augstskolas organizācijas projekta iniciatoriem, jau pieminētais teologs K. Kundziņš, pēc Bermonta uzbrukuma sastādīja paziņojumu ārvalstīm, kurā nosodīja šādu agresiju un lūdza atbalstu no pasaules zinātniskām aprindām. Šo uzsaukumu parakstīja gan Augstskolas organizācijas komisijas dalībnieki, gan citi mācībspēki, tostarp arī vācbaltieši, bet P. Valdena vārda starp parakstītājiem nebija. ${ }^{66}$ Tādā veidā P. Valdens netieši demonstrēja savu attieksmi pret notikumiem Latvijā. Izglītības ministrs K. Kasparsons rīkojumu par P. Valdena aizvietošanu ar P. Dāli izdeva 1919. gada 26. novembrī, t. i., nākamajā dienā pēc Pagaidu valdības apspriestās un Vācijai nosūtītās notas par karastāvokli abu valstu starpā. ${ }^{67}$

Pēc Otrā pasaules kara sarakstītajās atmin̄ās P. Valdens sevi pieskaitīja pie "bēgliem”, kas devušies uz Vāciju 1919. gada vasarā, lai glābtos no revolucionārajiem komunistiem. ${ }^{68}$ Tas nav patiesi, jo lielinieki tobrīd jau vairākus mēnešus atkāpās, bija piedzīvojuši sakāvi, un Latvijas teritorijas pilnīga atbrīvošana bija tuvāko nedēḷu jautājums, arī lielinieku popularitāte sabiedrībā jau bija strauji kritusi, turklāt lielinieki taču bija izraudzijjušies P. Valdenu arī par pašu veidotās augstskolas vadītāju. Savukārt 1924. gadā, aprakstot Latvijas Augstskolas dibināšanu, P. Dāle diplomātiski izvairīgi rakstīja, ka P. Valdens esot aizbraucis "zinātniskā komandējumā" uz Vāciju un "dažādu apstākḷ dēḷ neatgriezās vairs atpakal̦". ${ }^{69}$ Šis diplomātiskais formulējums iegājies arī Latvijas zinātnes vēstures pētījumos. $^{70}$ Situāciju skaidrāku nepadara arī tolaik Latvijas Preses biroja izplatītā ziņa, ka P. Valdens aizbraucis 1919. gada 16. augustā Izglītības ministrijas uzdevumā, proti, kā departamenta direktors (ierēdnis), lai “ārzemēs organizētu mācību lìdzekḷu savākšanu Latvijas Augstskolai”. ${ }^{71}$ Protams, tik sarežgìitos kara, juku un atbildīgu administratīvu uzdevumu apstākḷos "zinātnisks komandējums" vai "grāmatu vākšana” izklausās neticami. Visdrīzāk te ir runa par neapmierinātību ar P. Valdena attieksmi pret līdzšinējiem politiskajiem procesiem. Visai labā atmināa bija norises 1905. gada revolūcijas laikā. Tobrīd studenti vēlējās iesaistīties augstskolas pārvaldē, vinuus neapmierināja augstskolas vadības un daḷas pasniedzēju konservatīvisms, kā arī atbalsta trūkums revolucionārajai kustībai un iebildumi pret regulāru sanāksmju (politisko mītinuu) rīkošanu Politehnikuma telpās. ${ }^{72}$ 1905. gada janvāra pirmajā pusē studentu sanāksmes Politehnikuma telpās bija ikdienišḳa parādība. Direktora P. Valdena ierašanās uz kādu no nelegālajām sanāksmēm 1905. gada 14. janvārī studentus nemaz nenomierināja, tādēḷ lekciju lasī̌sana tika pārtraukta un institūta vadība neredzēja iespējas drīzumā atjaunot normālu mācību iestādes darbu. ${ }^{73}$ Vēlāk institūts atsāka darbu ierobežotā veidā, taču tikai uz neilgu laiku. Nemieru rezultātā augstskolu slēdza līdz 1906. gada augusta beigām.

Patiesībā revolūcija neizgaisa no akadēmiskās vides atminas visu starpkaru periodu - pārāk dramatiskas un spraigas bija šīs norises. Un, lai arī vairākums šī laika studentu bija dzimuši jau pēc revolūcijas, priekšteči mēdza krāšņi izstāstīt tālaika norises. Spilgts piemērs ir minētais Universitātes ilggadējais šveicars (durvju sargs un ne tikai) P. Miḳelsons. 1935. gadā viņš presei, piemēram, stāstīja, ka studenti uz augstskolas priekšniecību metuši pudeles ar smirdīgiem kịimiskiem šķidrumiem un Inženierzinātṇu fakultātē pat iesvieduši laboratorijā paštaisītu "bumbu". ${ }^{74}$ 1905. gada 28. oktobrī Latviešu Otrā teātra telpās (vēlāk - Jaunais Rīgas teātris) vispārējā studentu sanāksmē pulcējās ap 1000 studentu, vairākums pieprasīja atcelt 
no augstskolas direktora posteņa P. Valdenu kopā ar viņa palīgiem. ${ }^{75}$ Tã iespaidā jau tajā pašā dienā P. Valdens izvērstā iesniegumā lūdza augstskolas padomei atbrīvot vinuu no direktora amata, ${ }^{76}$ bet 1906 . gada 1. janvārī devās uz ārzemēm, pamatojot to ar ārstēšanos, bet patiesībā bēga no atriebības. ${ }^{77}$ Brīdī, kad veidojās Latvijas Augstskola, P. Valdens to atminējās kā nepamatotu studentu naida izpausmi, pēc gadiem gan atzina, ka revolucionāros musinātājus no augstskolas tomēr bija padzinis un tādēḷ sekojusi neapmierinātība. ${ }^{78}$ Patiesībā studentu atskaitīšana tolaik bija masveida parādība. Kopš 1902. gada augstskola l̦oti rūpīgi kontrolēja studentus, par politiski aktīvajiem vāca informāciju, ziṇoja drošības iestādēm utt. Dokumentācija bija P. Valdena akceptēta un parakstīta. ${ }^{79} \mathrm{Nav}$ brīnums, ka no studijām atskaitītajiem un viņu domubiedriem visu atlikušo mūžu, vēl ilgi starpkaru periodā, saglabājās naids pret augstskolas bijušo vadību un atsevišķiem mācībspēkiem.

Savukārt 1920. gada sākumā jaunāko "Valdena lietu" (toreiz tā to sāka saukt) izskatīja Latvijas Izglītības biedrības augstskolu sekcijā, kas atzina, ka pret P. Valdenu vērstie apvainojumi ir "netaktiski un neattaisnojami". ${ }^{80}$ Par to, ka P. Valdena aizbraukšana 1919. gadā tomēr bija politiski motivēta un "Valdena lietai" ir pamats, liecina asā vārdu apmaiņa avīzē "Latvijas Vēstnesis", kas izcēlās 1924. gadā. Šajā gadā saskan̄ā ar LU vadības aicinājumu P. Valdens ieradās Rīgā un Latvijas Universitātē nolasīja piecas vieslekcijas par moderno k̦īmiju. ${ }^{81}$ Polemika aizsākās ar to, ka 1919. gada notikumu aculiecinieks, latviskās augstskolas idejas aizstāvis, LU fizikas docents, vēlākais ilggadējais Matemātikas un dabaszinātṇu fakultātes dekāns Fricis Gulbis "Latvijas Vēstnesī” publicēja vienu un pēcāk atbildei otru rakstu, kuros pauda, ka P. Valdens apjūsmojis vācu karavīru ienākšanu Rīgā 1919. gada maijā un terora sākšanu pret latviešiem..$^{82}$ No Latvijas viņš 1919. gadā esot aizbraucis kopā ar naudu, kas viṇam uzticēta mācību materiālu iegādei, un san̄ēmis atalgojumu pat vēl pēc P. Bermonta sakāves, kaut gan tobrīd bija jau lūdzis Vācijas pavalstniecības pieškiršanu. "Valdens [...] aizbrauca apzinigi un ar nodomu [...] Latvijai un vinas augstskolai viňš nav ticējis [...]"83 Tā emocionāli rakstīja F. Gulbis; viṇa tuvs radinieks no mātes puses bija revolucionārs un viens no pirmajiem neatkarīgas Latvijas idejas aizstāvjiem Ernests Rolavs, kuru pēc bēgḷa gaitām vācbaltiešu muižnieki apcietināja, piekāva un nošāva 1907. gadā pie Grobinas. ${ }^{84}$

Pēc F. Gulbja rakstiem presē aizstāvēt P. Valdenu metās pazīstamais tautsaimniecības profesors un labs P. Valdena pazina no Vācijā pavadītā perioda - K. Balodis, kurš divos emocionālos rakstos apgalvoja, ka P. Valdens taču pat mācējis runāt latviski, bet uz Latvijas Augstskolas atvēršanu 1919. gada 28. septembrī neesot varējis no Vācijas ierasties slimības un līdzekḷu trūkuma dēl. ${ }^{85}$ Līdzīgi arī Latvijas pirmā ārlietu ministra Zigfrīda Annas Meierovica palīgs un labs K. Baloža draugs matemātiķis, praktizējošs diplomāts un pazīstamais žurnālists Henrijs Simsons noraidīja izskanējušos pārmetumus par P. Valdenam "trūkstošo nacionālismu" un cildināja viņa zinātniskos sasniegumus. ${ }^{86}$ Abu P. Valdena aizstāvju raksti gan jāuztver drīzāk kā viņu personīga simpātija un nekas vairāk, jo 1919. gadā viṇi nebija iesaistīti Latvijas Augstskolas izveidē un atradās ārzemēs (K. Balodis - Vācijā, bet H. Simsons - Lielbritānijā), tādēl par notikušo zināja maz. K. Balodis turpmāk iemantoja l,oti pretrunīgu slavu, jo mēdza dīvainā manierē paust visai juceklīgus uzskatus, bet H. Simsons vinuu pat varbūt pārspēja, par ko liecina vina pirmskara sarakstes paziņas Jāṇa Pliekšāna (Raiṇa) atstātās liecības par H. Simsona "nenormālību" un vēlākā ārstēšanās psihiatriskajā slimnīcā. ${ }^{87}$ 
P. Valdenam Latviju pametot un vāciskās elites ietekmei valstī sarūkot, 1919. gada izskaṇā iezīmējās konsekvence nacionālās augstskolas izveides virzienā. Vadību pārṇēmušais filozofs P. Dāle labāk apjauta humanitāro nozaru nepieciešamību jaunajā Latvijas valstī un jaunajai latviešu nācijai. Bez stipras humanitāras nozares nevarēja izveidot stabilu akadēmiski intelektuālu un patriotisku vidi gan augstskolā, gan valstī kopumā. Veidojot valsts augstskolu, īstenojās tas pats princips, kas valsts pārvaldē, - noteicošam bija jākḷūst demokrātiskajam vairākumam, proti, latviešiem. Latviešiem kā vairākumam bija nepieciešams uz valsts izglītību balstīts garīgo vērtību pamats. Brīdī, kad komisijas sastāvā sāka iezīmēties latviešu demokrātiskais vairākums, kḷuva skaidrs, ka Politehnikuma akadēmiskā struktūra būs krietni jāpaplašina humanitāro zinātṇu virzienā. Šajā jomā l,oti rosīgs bija tieši P. Dāle, kurš konsekventi iestājās par Filologijas un filozofijas fakultātes izveidi, kuras paspārnē varētu attīstìt tādas latviešiem nozīmīgas zinātṇu jomas kā vēsture, valodniecība, filozofija. ${ }^{88}$ Tāpat viņš aktīvi atbalstīja Teoloǵijas fakultātes izveidi. ${ }^{89}$ Arī šī joma bija ārkārtīgi svarīga un saistīta ar jaunās demokrātiskās valsts pamatprincipiem. Teoloǵijas fakultātes ietilpināšana augstskolā nozīmēja abu valsts lielāko kopienu - luterāṇu un katoḷu - zināmu savaldīšanu un tuvināšanu. Gan luterāṇu baznīca, gan katoḷi līdz tam brīdim bija atradušies vecās elites, tostarp muižniecības, kontrolē (muižnieku patronāts), turklāt arī šeit uzskatāmi iezīmējās vāciskā dominante. Abas kristīgās konfesijas pārstāvēja divas nosacìtas kultūrtelpas - luterāṇi bijušās Baltijas gubern,as, bet katoḷi Vitebskas guberṇu (Latgale) -, kuras ilgstoši bija savstarpēji noškirtas. Latvijas sabiedrība kopumā bija tradicionāli dievbijīga, tādēḷ akadēmiska kontrole pār reliğijas jomu bija svarīgs aspekts, lai stiprinātu politisku stabilitāti valstī. İpašs jautājums bija Latgales kulturālās autonomijas prasības, kuras uzturēja katoḷticīgās kopienas pārstāvji, redzamākie latgaliešu valodas un kultūras aizstāvji, politiķi un literāti Francis Trasuns un Francis Kemps. Tādēl Teolog̣ijas fakultātes izveidi varēja pieskaitīt pie pasākumiem Latgales separātisma novēršanai. Arī te atradās neapmierinātie. Visvairāk šādu fakultātes izveidi parlamentārās demokrātijas laikā kritizēja lielākais politiskais spēks - sociāldemokrāti. Vini pieprasīja reliǵijas pilnīgu izslēgšanu no valsts aprites, nesaredzēja tajā neko akadēmisku, tikai māṇticību, daudzkārt pieprasīja Teologijas fakultātes slēgšanu, tās likvidēšanu iekḷāva pat partijas 1930. gada programmā. ${ }^{90}$

LU akadēmiskā vide bija būtiska sastāvdaḷa starpkaru perioda Latvijas sabiedrības elitē, tādēḷ tai bija cieša saistība ar politiku, tikai par to mēdza visai maz runāt.

Parlamentārisma gados dạ̣a LU mācībspēku aktīvi iesaistījās lielajā politikā, bieži uznēmās izglītības ministra amatu. Par ministriem kḷuva filologijas profesors Juris Plāķis (no 1920. gada 12. jūnija līdz 1921. gada 26. aprīlim), vecākais ekonomikas docents Longīns Ausējs (ministrijas pārvaldnieks no 1921. gada 27. aprīḷa līdz 18. jūnijam), filolog̣ijas profesors Aleksandrs Dauge (no 1921. gada 19. jūnija līdz 1923. gada 26. janvārim), filologijas profesors Kārlis Straubergs (no 1924. gada 27. janvāra līdz 18. decembrim), filolog̣ijas profesors E. Felsbergs (no 1924. gada 19. decembra līdz 1925. gada 4. martam), kīmijas profesors Arvīds Kalniņš (no 1925. gada 5. marta lìdz 23. decembrim), inženierzinātṇu profesors Edmunds Ziemelis (no 1925. gada 24. decembra līdz 1926. gada 17. decembrim un no 1928. gada 2. decembra lìdz 1931. gada 4. decembrim), vēstures profesors Augusts Tentelis (no 1928. gada 23. janvāra līdz 1. decembrim). ${ }^{91}$ No 17 reizēm, kad biežo valdības krīžu dēḷ tika meklēti Izglītības 
ministrijas vadītāji, deviņas reizes tie tika atrasti LU mācībspēku aprindās. Kā redzams, lielākoties tie bija humanitāro nozaru pārstāvji, jo tieši vini tolaik vislabāk spēja formulēt nacionālās izglītības un zinātnes mērḳus un uzdevumus, citiem vārdiem - bija šīs jomas vadošie ideologi. Turklāt LU profesori bija visi trīs autoritārisma perioda izglītības ministri (teologíjas profesors - fakultātes dekāns Ludvigs Adamovičs, vēstures profesors - rektors A. Tentelis, kiīmijas profesors - dekāns, rektors Jūlijs Auškāps). Tādējādi nacionālās augstskolas autoritāte šajā laika posmā bija neapstrīdama izglītības politikas jomā, var pat teikt, ka autoritārisma perioda izglītības un zinātnes politika bija LU veidota. Daḷeji Alma Mater bija veidota pat visa autoritārisma ideolog̣ija Latvijā.

Latvijas Augstskolas un vēlākās LU pārstāvji l̦oti agri bija nonākuši varas pašā augstākajā līmenī, jo tie bija pieskaitāmi pie sākotnēji visai šaurā latviešu sabiedriski politiskā virsslān,a. Tā jau 1919. gada novembrī Augstskolas organizēšanas komiteja Tautas Padomes priekšsēdētāju Jāni Čaksti ievēlēja par jurisprudences profesoru. J. Čakste aktīvi līdzdarbojās augstskolas organizēšanā un lasīja lekcijas līdz 1922. gadam, kad Saeima vinuu izraudzījās Valsts prezidenta amatam. ${ }^{92}$ J. Čakste bija Demokrātiskā centra galvenā politiskā figūra. Tā bija partija, kurā apvienojās daudzi sabiedriski darbinieki. No šis partijas J. Čaksti 1920. gadā ievēlēja Satversmes sapulcē, kā arī 1. un 2. Saeimā. 1. Saeimā no šī paša saraksta ievēlēja toreizējo Latvijas Augstskolas rektoru E. Felsbergu, bet 3. un 4. Saeimā arī LU docentu biologu Kārli Kiršteinu..$^{93}$ Tomēr šis nebija vienīgais politiskais spēks, kas bija simpātisks akadēmiskajai elitei.

Vairāki LU mācībspēki pieslējās redzamā politiķa, jurista Arveda Berga Latviešu nacionālajai apvienībai, viṇa vadītais laikraksts "Latvis" bija asā opozīcijā spēcīgākajai Latvijas Sociāldemokrātiskajai strādnieku partijai un tās laikrakstam "Sociāldemokrāts". 1925. gada Rīgas domes vēlēšanu sarakstā no 90 šìs partijas kandidātiem desmitā daḷa bija prominenti LU docenti un profesori (L. Ausējs, J. Auškāps, Ernests Birkhans, Jānis Jankovskis, Arveds Leppiks, M. Prīmanis, K. Rezevskis, Vilis Vìtols, E. Zarinšs). Arī rektoram E. Felsbergam simpatizējuši A. Berga uzskati. ${ }^{94}$ No minētajiem ekonomikas docentam L. Ausējam izdevās kḷūt par 2. un 3. Saeimas deputātu.

Redzamu vietu politiķu vidū ieņēma pazīstamais tautsaimniecības un demogrāfijas profesors, pārtikas kartīšu sistēmas izgudrotājs K. Balodis. Viņš l,oti, varbūt pat vairāk nekā citi vina amata brāḷ no LU vēlējās iesaistīties politikā, īpaši viṇam rūpēja saimniecības attīstība. 1919. gadā pārbraucis Latvijā no Vācijas, viṇš iestājās Latvijas Sociāldemokrātiskajā strādnieku partijā, bet, nesaṇemdams atbalstu savām idejām, izveidoja pats savu mazpartiju Latvijas Darba savienību un tautas apvienību - un aktīvi turpināja paust kreisus ekonomiskus priekšstatus, tādēl iemantoja daudzus nelabvēḷus pilsoniskajās aprindās un arī LU akadēmiskajā vidē. ${ }^{95}$ Zināmas paralēles ar mūsdienām iezīmē šīs partijas devīze: "Mēs solām, jo zinām, ka spējam savus solijumus pildit!"96 1928. gada novembrī no šīs partijas K. Balodis bija ievēlēts par 3. Saeimas deputātu, bet pēc viña pēkšñās nāves šo amatu ieņēma kandidātu saraksta otrais numurs, vina draugs un svainis, bijušais "Mājas Viesa" un "Dienas Lapas" redaktors LU filozofijas profesors Pēteris Zālīte. ${ }^{97}$

No akadēmiskās vides nākušie politiķi bija visai atšḳirīgi no pārējiem deputātiem un ar savu mērenību un inteliǵenci bieži neiederējās skaḷajā, tirgum līdzīgajā Saeimas arēnā, kur daudzi tikai sāka apgūt demokrātijas pieredzi. Tāpat nevar teikt, ka no šiem politiķiem kāds būtu kḷuvis 
populārs sabiedrībā. Drīzāk sabiedrība saskatīja dažādas dīvainības, kas piemita politikā nonākušajiem profesoriem un docentiem un nekautrējās par tām pazoboties. Tā, piemēram, satīras žurnāls "Svari” LU rektoru E. Felsbergu, kurš 1924. gada rudenī bija izstājies no Demokrātiskā centra, divdomīgi sauca par "ekscentriki". ${ }^{98}$ Ipaši bieži prese mēdza pazoboties par jau pieminētajiem politiḳiem - profesoriem K. Balodi un P. Zālīti, kurus uztvēra kā nedalāmu politisku tandēmu, kas viens otru apstiprina un papildina. Tā, piemēram, "Svaros" lasām, ka deputāti "vismị̄āak lustējas ap prof. Balodi" - tikko profesors kāpj tribīnē, tā deputāti tūlin "pieñem valı̆gākas pozas un vinu sejām pārlido bezbēdīgs smaids - "Tūlin būs lustes!" vinu acis labsirdìgi saka". ${ }^{99} \mathrm{Kad}$ P. Zālīte deputāta amatā aizstāja savu mirušo svaini un kolēǵi K. Balodi, viņš kḷuva pat par sistemātisku zobgalību upuri. ${ }^{100}$

\section{Autoritārisma tendenču iespaidā}

Kopš autoritārisma nostiprināšanās 1934. gada maijā akadēmisko brīvību un demokrātiju uzskatos LU pakāpeniski sāka aizstāt autoritārs klišejisms, aizkulišu noslēpumainība, cenzūra un improvizēta pašdisciplīna. Iepriekš avīzēs un sanāksmēs plaši apspriestās LU problēmas vai personību konflikti vairs nepārtapa rakstītā vārda formā. Kulmināciju šīs pārvērtības škietami sasniedza 1937. gadā, kad K. Ulmanis svinēja 60 gadu jubileju. Viņš vienmēr bija alcis, lai sabiedrība viņa nopelnus Latvijas izveidē uzskatītu par nepārspētiem, un LU aprindās to labi zināja. Tagad LU augstākās raudzes pārstāvju publikācijas atainoja gluži vai idillisku vidi Latvijā un ideālu tautas vadoni. Tā, piemēram, tā brīža izglītības ministrs un Latvijas Vēstures institūta direktors profesors A. Tentelis sarakstīja slavinošu K. Ulmaṇa biogrāfiju, kurā viņu cildināja par "īsteno Latvijas tēvu", vadoni, kura katrs vārds sakṇojoties latviešu zemē un rodot atbalsi latviešu sirdī. ${ }^{101}$ Savukārt LU rektors J. Auškāps slavināja latviešu identitāti, vienotību, gara spējas un gribu nodoties zinātnei, dēvēja K. Ulmani par "mūsu valsts celtnes lielo arhitektu", kas tās augstā torṇa virsotnē iededzis "gaišo zinātnes lāpu”, savās uzrunās regulāri aicināja sekot "vadonim" nacionālās valsts stiprināšanā. ${ }^{102}$

Autoritārisma laiks radīja iespaidu, ka Latvijas sabiedrība, tostarp akadēmiskā vide un inteliǵence, ir harmoniski saliedēta. Turpretim agrāk, parlamentārisma gados, varēja rasties gluži pretējs iespaids. Tā, piemēram, publiski bija vērojams, ka ārpus LU aprindām nākušo izglītības ministru attiecības ar tādiem, kuri pārstāvēja LU, gandrīz vienmēr bija saspringtas, pat naidīgas. Demokrātijas un preses brīvības laiks to nekādi nevarēja noslēpt. Bijušā Filolog̣ijas un filozofijas fakultātes dekāna un ievērojamā latviešu diplomāta Arnolda Spekkes vārdiem izsakoties, LU parlamentārisma gados atradās "ideolog̣iski nacionālā frontē". ${ }^{103} \mathrm{Te}$ visai skaidras liecības ir saglabājušās par izglītības ministra J. Pliekšāna saspīlētajām attiecībām ar LU rektoru A. Tenteli. Rainis bija internacionālists, sociālists, un viņam nepatika A. Tenteḷa nacionālpatriotiskā vēstures koncepcija. Viņš sekmēja liberālisma izpausmi akadēmiskajā vidē, atbalstīja privāto augstskolu izveides idejas. 1926. gada februārī grāmatu apgāda vadītājs un Nacionālās operas direktors Ansis Gulbis vērsās pie LU Filologijas un filozofijas fakultātes ar ierosinājumu rekomendēt Raini Nobela prēmijai literatūrā. ${ }^{104}$ Latvijā tolaik valdīja uzskats, ka pieteikt kandidatūras prēmijai drīkst akadēmiskas institūcijas un augstskolas, kaut gan patiesībā to tolaik Eiropā darīja arī privātpersonas. ${ }^{105}$ LU nostāja šajā jautājumā bija noraidoša, tā izvairījās Raini izvirzīt prēmijai, to neizdarīja arī kāda cita institūcija vai privātpersona. ${ }^{106}$ Presē figurēja argumenti, ka Rainis iepriekšējā gadā 
neesot sarakstījis neko nozìmīgu, un arī iesnieguma termiņš 31. janvāris bijis nokavēts, tomēr par patieso iemeslu uzskatīja to, ka Rainis bija sociāldemokrāts un parlamentārisma periodā tika uzskatīts tikai par vienas škiras (strādniecības) dzejnieku, proti, par tādu, kas nereprezentēja visu sabiedrību. Šādu viedokli pauda, protams, labējā prese, tostarp Zemnieku savienības "Brīvā Zeme" un A. Berga "Latvis", kam simpatizēja latviešu akadēmiskā vide. ${ }^{107}$ Īpaši konsekventi pret Raini nostājās bijušais izglītības ministrs, LU prorektors un padomes loceklis, vēlākais Filologijas un filozofijas fakultātes dekāns, salīdzināmās valodniecības profesors J. Plāḳis, ${ }^{108}$ kurš visai bieži mēdza lekcijās zoboties par J. Pliekšāna pseidonīmu Rainis, stāstot, ka lietuviešu valodā tas nozīmējot "raibais", tā iespaidā J. Plāḳis bieži vinu ironiski saukājis par "tīǵgeri". ${ }^{109}$ Situāciju vēl saspringtāku padarīja tas, ka Rainis, līdzīgi kā visa M. Skujenieka kreisi centriskā valdība, atbalstīja ideju par vācbaltiešu veidotu privāto augstskolu - Herdera institūtu Rīgā (Herderinstitut zu Riga). Latviešu labējā inteliǵgence 1927. gadā centās bremzēt institūta likumprojekta izstrādi.

Šì epizode iezīmēja latviešu akadēmiskās vides politiskās noslieces. Vairākumam akadēmiskās vides pārstāvju bija raksturīgs konservatīvisms, ko 30. gados papildināja izteiktāka nacionāla ievirze. Tas gan neliedza viniem kādā politiskas dabas vai saimnieciskā jautājumā pieslieties kreisiem vai labējiem politiskiem uzskatiem.

30. gadu otrajā pusē sāka iezīmēties starptautiskās situācijas saspīlējuma kāpums, ko izraisīja Vācijas varenības atjaunošanās. K. Ulmaṇa valdības aprindas izlēma, ka šādā situācijā ir svarīgi veicināt patriotismu, sabiedrības militāro sagatavotību un atbalstu Latvijas armijai arī studentu vidē. 1937. gada 27. aprīlī valdība izdeva Noteikumus par militāro audzināšanu un militāro apmācību publiskās un privātās mācības iestādēs. ${ }^{110}$ Ar to valdība veica nozīmīgas korekcijas, LU programmā ieviesa militāro apmācību kā obligātu priekšmetu ar 40 stundām gadā un pakḷāva tai visus vīriešu kārtas studentus līdz 40 gadu vecumam, atskaitot vienīgi tos, kas strādāja valsts dienestā.

Šāda militārā apmācība bija jānodrošina un jāfinansē pašai augstskolai, organizējot priekšlasījumus, ekskursijas, piedalīšanos parādēs un svinīgajos aktos un citus līdzīgus pasākumus. LU visai kūtri iesaistījās militārās apmācības organizēšanā, jo tai nebija izdevīgi finansēt šādas papildu studijas. Turklāt liela dala profesoru un tostarp tradicionāli arī Universitātes vadība bija visai pacifistiski noskaņota. Kara resors kḷva uzstājīgs un kategorisks - Armijas štābs 1937. gada 25. oktobrī uzdeva jaunievēlētajam rektoram M. Prīmanim uzsākt militārās apmācības. ${ }^{111}$ Rezultātā militārai apmācībai LU sāka algot Armijas štāba izraudzītus lektorus. Sākotnēji to skaits bija apmēram 20 virsnieku, bet līdz 1940. gadam tas pieauga līdz 50. ${ }^{112}$ Nemot vērā, ka pirms K. Ulmaņa apvērsuma profesoru skaits LU nesasniedza vienu simtu, šādu militāro lektoru īpatsvars bija patiesi iespaidīgs. Lai arī valdības rīcība ir uzskatāma par racionālu ieguldijjumu Latvijas drošības un aizsardzības spēju vairošanā, varēja just, ka LU akadēmiskās aprindas uztvēra militāros lektorus ar skepsi, pat zināmu augstprātību. Militāro lektoru uzvedībai un zināšanām nereti bija neakadēmisks raksturs, viṇi pakḷāvās nevis akadēmiski godājamās Alma Mater normām un profesoriem, bet gan paši saviem Armijas štāba apmācības daḷas ieceltajiem galvenajiem lektoriem (līdz okupācijai tādi bija štāba kapteiņi Kārlis Mangulis, Teodors Galdiņš un Teodors Bebris). ${ }^{113}$

1939. gads nesa lielas pārvērtības valsts un Universitātes dzīvē. PSRS un Vācijas tuvināšanās dēḷ strauji mainījās starptautiskā situācija, 23. augustā tika noslēgts 
Molotova-Ribentropa pakts, tam sekoja PSRS karabāzu izveide, un 30. oktobrī tika noslēgts līgums par vācbaltiešu izceḷošanu uz Lielvāciju. Šie notikumi l̦oti strauji mainīja kadru un etnisko situāciju un vispārējo noskaņojumu LU. Gadu gaitā vācu mācībspēku skaits augstskolā jau tā bija samazinājies no maksimāli 58 līdz 29 izceḷošanas priekšvakarā, bet īpatsvars - no 14\% 1922.-1923. gadā līdz apmēram 5\% 1938.-1939. gadā. ${ }^{114}$ Tagad dažu nedēḷu laikā LU strauji zaudēja atlikušos vācu mācībspēkus. Jau pirmajā novembra nedēḷā izceḷošanai uz Vāciju pieteicās vairāk nekā puse vācu pasniedzēju. Vēl daži, kā, piemēram, ilggadējais Inženierzinātṇu fakultātes profesors, Eiropā atzìtais geodēzists A. Buholcs, izceḷoja vēlāk - 1941. gadā. ${ }^{115}$ Vienu no palikušajiem, Medicīnas fakultātes asistentu, kādreizējo brīvības cīnu dalībnieku vācbaltiešu landesvērā, Nikolaju Reinicu (Nikolai Reinitz), īsi pirms vācu karaspēka ienākšanas Rīgā nošāva Centrālcietumā par pretpadomju darbību. ${ }^{116}$ Cik zināms, tikai viens vācietis, Mehānikas fakultātes docents, elektrotehnikas speciālists Ludvigs Hunhens (Ludwig Hunchen), turpināja zinātnisko darbu vēl pēckara Latvijā, turklāt pēc savu tautas brāḷu izceḷošanas 1939. gada oktobrī kḷuva par tā saukto "ārkārtas" profesoru. ${ }^{117}$ Protams, izcel̦ošana attiecās arī uz vācu studentiem. Vācbaltiešu izcelıšanas rezultātā 1939. gada novembra sākumā visas LU fakultātes kopumā zaudēja 143 studentes, ${ }^{118}$ tomēr, kā atreferēja tālaika prese, izceḷot grasījās visi 250 LU studējošie vācieši un vācietes. ${ }^{119}$

Saistībā ar vācbaltiešu aizbraukšanu valdībai kopā ar LU bija steidzami jārisina aizbraukušo pasniedzēju aizstāšanas jautājums, jo studiju semestris jau bija sācies. Preses cenzūras un aizliegto sabiedriski politisko brīvību iespaidā klīda baumas, ka pēc vāciešu aizbraukšanas Latvijā radīsies inteliǵgentu darbinieku trūkums. Daži pat bija iedomājušies, ka pašreizējiem studentiem augstskolas vadība varētu noteikt samazinātas prasības, lai ātrāk aizpildītu tukšās amata vietas. ${ }^{120}$ Studijās prasības gan oficiāli netika samazinātas, toties rudens semestra vidū studiju procesā LU bija radies īsts juceklis. Izceḷotgribētājiem bija pāris nedēḷu laikā jāpabeidz viss iesāktais, un šajā saspringtajā situācijā katrs centās to atrisināt sev izdevīgākā veidā. Vakantas kḷuva nepieredzēti daudzas profesoru vietas. Radās izdevīgāka situācija tiem, kas kāroja iegūt augstāku amatu, turklāt bez īpašas konkurences no kolēguu puses. Valdība izdeva Latvijas vēsturē vēl nebijušu rīkojumu par masveida tā saukto "ārkārtējo" profesoru iecelšanu. ${ }^{121}$ Šis valdības solis ḷoti labi parādīja, cik spēcīga tomēr ir bijusi vācu izcelsmes profesoru nozīme LU līdz 1939. gada rudenim. Tiem aizbraucot, bija nepieciešama bezprecedenta profesoru kadru papildināšana. PSRS uzspiestais bāzu līgums un līgums ar Vāciju par vāciešu izcel̦ošanu, no vienas puses, radīja LU akadēmiskajā saimē bailes par nākotni un tuvojošos karu, bet, no otras puses, pēc vācbaltiešu aizbraukšanas radās unikāla iespēja 45 ilggadējiem latviešu pasniedzējiem strauji uzkāpt līdz akadēmiskās karjeras kāpṇu virsotnei - kḷūt par tā dēvētajiem "ārkārtas" profesoriem. Kā optimistiski rakstīja tālaika oficiālā prese: "Mūsu jauno zinātnieku kadrs sekmīgi aizstās aizbraucējus!"122 Viss notika tik strauji, ka pat nebija laika izdomāt, kā jaunpienākušos amatus pareizāk integrēt pastāvošo akadēmisko amatu un atalgojuma sistēmā un kā panākt, lai netiek pārkāpti akadēmiskie godīguma principi amatu ieñemšanā. Bija atlicis vairs tikai nedaudz vairāk kā pusgads, līdz Alma Mater, gluži tāpat kā visa valsts, tiks pakḷauta PSRS īstenotajai sovetizācijai. Ar to uz turpmākiem gadu desmitiem tika pārtraukta nacionālās universitātes dzīve. 


\section{ATSAUCES UN SKAIDROJUMI}

${ }^{1}$ Juridiski precīzu skaidrojumu par augstskolas priekštečiem 1927. gada 29. martā sagatavoja galvenais augstskolas juriskonsults, docents, vēlākais Latvijas Senāta (Augstākās tiesas) senators vācbaltietis Augusts Lēbers (August Loeber). Ar to noslēdzās vairākus gadus akadēmiskajās aprindās ilgušās diskusijas par augstskolas priekšteču nozīmi un patieso dibināšanas brīdi. Sk.: Sarakste ar Izglītības ministriju un ziņas par mācību spēku apbalvošanu ar Triju Zvaigžnu ordeni, par amata tērpu u. c., 1920.- 1938. Latvijas Nacionālais arhīvs, Latvijas Valsts vēstures arhīvs, Rīga (turpmāk - LNA LVVA), 7427-6-122, 70. lp.

${ }^{2}$ Latvijas Augstskolas organizācijas Padomes protokoli, 1919-1921. Ibidem, 7427-6-1, 19. lp.

${ }^{3}$ Ibidem, 97. 1p.

${ }^{4}$ RAIMONDS CERŪZIS. Latvijas vācu privātā augstskola "Herdera institūts" (1921-1939): izglītība, zinātne, tradīcija un ideolog̣ija. In: RAIVIS BIČEVSKIS (sast.). Heidegera Rīgas rudens: Martins Heidegers Rīgā. Rīga 2011, 269.-286. lpp.

${ }^{5}$ Latvijas Augstskolas organizācijas Padomes protokoli, 1919-1921. LNA LVVA, 7427-6-1, 40. lp.

${ }^{6}$ Ibidem, 2. 1p.

${ }^{7}$ Album Livonorum. Dorpat 1822-1939. [Lübeck] 1958, S. 301, 339.

${ }^{8}$ Paskaidrojums, Frīdrihs Brēdermans. In: Baltijas Ziṇas, 18.11.1918., 3. lpp.

${ }^{9}$ Ievērojama latviešu sapulce Rīgā. In: Dzimtenes Ziņas, 05.01.1918., 1.-2. lpp.; Pirmais Rīgas latviešu organizēšanās solis pēc vācu ienākšanas Rīgā. In: Baltijas Ziņas, 13.11.1918., 3. lpp.

${ }^{10}$ [Saraksts] Nr. 7., Kristīgā Nacionālā Partija. In: Baltijas Vēstnesis, 13.04.1920., 4. lpp.

${ }^{11}$ Von der akademischen Versammlung. In: Rigasche Zeitung, 10.12.1917., S. 3.

${ }^{12}$ Latvijas Augstskolas organizācijas Padomes protokoli, 1919-1921. LNA LVVA, 7427-6-1, 10. lp.

${ }^{13}$ P. Miḳelsons, Universitātes galvenais šveicars. In: Pēdējā Brīdī, 01.10.1935., 3. lpp.; 35 gados bez nokavēšanās. Rīts, 01.10.1935., 6. lpp.

${ }^{14}$ Acta der Baltischen Tehnischen Hochschule Riga. Betref. Verschiedenes, 1918-1919. LNA LVVA, 7145-4-8, 114. 1p.

${ }^{15}$ Ibidem.

${ }^{16}$ Sarakste ar Izglītības ministriju un ziṇas par mācību spēku apbalvošanu ar Triju Zvaigžņu ordeni u. c., 1920-1938. Ibidem, 7427-6-122, 42. lp.

17 JĀNIS VĒLIN̦š. Universitāte viṇam bija visa dzīve. In: Austrālijas Latvietis, 25.09.1970., 5. lpp.

${ }^{18}$ Gada pārskati par LU darbību, 1929-1939. LNA LVVA, 7427-6-39-1a-55, 78. lp.

${ }^{19}$ Materiāli par Politehniskā institūta pārṇemšanu Latvijas valsts rīcībā, 1919-1935. Ibidem, 7427-6-228, 32.-37., 178. lp.

${ }^{20}$ Ibidem, 92. 1p.

${ }^{21}$ Ibidem, 609.-610. lp.

${ }^{22}$ MĀRA KIOPE. Saruna ar Latvijas Universitātes pirmo rektoru profesoru Ernestu Felsbergu. In: SANDRA RANKA (sast.). Profesors Dr. phil. h. c. Ernests Felsbergs. Dzīve un darbs. Rīga 2004, 37.-43. lpp., šeit 42. lpp.

${ }^{23}$ O. Māzings vēlāk bija plaši pazīstams vietējā vācu kopienā, jo aktīvi pētīja Baltijas vāciešiem raksturīgos vārdus, runas un izteiksmju formas, vēlāk sagatavoja pat īpašu vārdnīcu. Pārgāja strādāt pie sava kolēǵa V. Klumberga vācu privātajā augstskolā Rīgā - Herdera institūtā.

${ }^{24}$ E. Veiss 1939. gadā izceḷoja uz Vāciju. Aus der Universität. In: Rigasche Rundschau, 27.10.1939., S. 5.

${ }^{25}$ E. Cimmermanis 1939. gadā izceḷoja uz Vāciju. Ibidem.

${ }^{26}$ V. Klumbergs vēlāk sarāva saikni ar Latvijas Augstskolu, aktīvi iesaistījās vācu privātās augstskolas, Herdera institūta, izveidē Rīgā un kḷuva par tās vadītāju lỉdz pat vācbaltiešu izceḷošanai 1939. gadā. 
${ }^{27}$ V. Vencelidesam starpkaru periodā piederēja $W$. Wencelides automobiḷu inženieru birojs, vin̄̌s tirgoja un remontēja prestižās Mercedes-Benz markas automašīnas, piedalījās autosacīkstēs ([Vencelidesa rīkotās automobiḷu sacīkstes - fotoreportāža]. In: Nedēḷa, 07.09.1923., 13. lpp.).

${ }^{28}$ Prof. Eižena Laubes personīgā lieta, LU Arhitektūras fakultāte. LNA LVVA, 7427-13-970, 13. lp.

${ }^{29}$ Latvijas Augstskolas organizācijas Padomes protokoli, 1919-1921. Ibidem, 7427-6-1, 12. lp.

${ }^{30}$ Pārskats par Latvijas augstskolas, vēlāk Universitātes, nodibināšanu un viņas darbību (1918-1929). Ibidem, 7427-6-37a, 262. lp.

${ }^{31}$ LU studentu statistika. LU studējošo skaits, 1919-1928. Ibidem, 7427-6-55, 564.-565. lp.

${ }^{32}$ Latvijas Augstskolas organizācijas Padomes protokoli, 1919-1921. Ibidem, 7427-6-1, 17. lp.

${ }^{33}$ Ibidem, 23. lp.

${ }^{34}$ Bijušā Rīgas politehniskā institūta pārṇemšanas komisijas protokoli (1919-1922). Ibidem, 7427-6-228, 423. lp.

${ }^{35}$ Zur Teuerung der Lebensmittel. In: Libauische Zeitung, 31.07.1920., S. 2; Verschiedenes, Die Preise in Riga. In: Libauische Zeitung, 17.08.1920., S. 2.

${ }^{36}$ Latvijas Augstskolas organizācijas Padomes protokoli, 1919-1921. LNA LVVA, 7427-6-1, 30. lp.

${ }^{37}$ Pārskats par Latvijas augstskolas, vēlāk Universitātes, nodibināšanu un viṇas darbību (1918-1929). Ibidem, 7427-6-37a, 113. lp.

${ }^{38}$ Ibidem, 103.-104. lp.

${ }^{39}$ Bijušā Rīgas politehniskā institūta pārṇemšanas komisijas protokoli, 1919-1922. Ibidem, 7427-6-229, 30.-31. 1p.

${ }^{40}$ Ibidem, 7427-6-228, 513. lp.

${ }^{41}$ Sarakste ar Izglītības ministriju un ziṇas par mācību spēku apbalvošanu ar Triju Zvaigžņu ordeni u. c., 1920-1938. Ibidem, 7427-6-122, 21., 26. lp.

${ }^{42}$ Ibidem, 31. lp.

${ }^{43}$ Prof. Eižena Laubes lieta. Ibidem, 7427-13-970, 193., 196. lp.

${ }^{44}$ Imanuela Bencingera lieta. Ibidem, 7427-13-153, 204., 210., 214. lp.

${ }^{45}$ Prof. Leonīda Arbuzova lieta. Ibidem, 7427-13-88, 127. lp.

${ }^{46}$ Pārskats par Latvijas augstskolas, vēlāk Universitātes, nodibināšanu un viņas darbību (1918-1929). Ibidem, 7427-6-37a, 103.-104., 385. lp.; Prof. Leonīda Arbuzova lieta. Ibidem, 7427-13-88, 36. lp.

${ }^{47}$ Izraksti no K. Morberga testamentāriem novēlējumiem, LU padomes protokoliem, K. Morberga radinieku lūgumi par pabalstiem, 1928-1931. Ibidem, 7427-8-12, 311. lp.

${ }^{48}$ Romas viesnīca Rīgā esot viena no vislabākām Eiropā - atzīst ārzemnieki. In: Centra Balss, 09.03.1934., 5. lpp.

${ }^{49}$ Der Ausbau des Hotels de Rome verzögert. In: Rigasche Rundschau, 04.12.1931., S. 6.

${ }^{50}$ Warum der Umbau des Hotel de Rome sich verzögert. In: Rigasche Rundschau, 07.12.1931., S. 10.

${ }^{51}$ Eröffnung des Hotel de Rome. In: Rigasche Rundschau, 10.09.1932., S. 10.

52 "Romas" atjaunošana. In: Latvijas Kareivis, 10.09.1932., 3. lpp.; "Romas" viesnīca un restorāns. Valdības Vēstnesis, 10.09.1932., 2. lpp.

${ }^{53}$ Romas viesnīca Rīgā esot viena no vislabākām Eiropā - atzīst ārzemnieki. In: Centra Balss, 09.03.1934., 5. lpp.

${ }^{54}$ Sarakste par Metropoles viesnīcas pārdošanu Latvijas Universitātei, 1940. LNA LVVA, 7427-8-20, 2. lp.

${ }^{55}$ Noteic jauno studentu uzṇemšanas kārtību. In: Latvijas Kareivis, 14.06.1940., 2. lpp. 
${ }^{56}$ Viesnīcas Metropol vācu īpašnieku izcelıošanas rezultātā to uz laiku slēdza, tās darbību atjaunoja jau pēc Latvijas inkorporācijas PSRS 1940. gada oktobrī. Sk. sludinājumus par viesnīcas darba atjaunošanu: Padomju Latvija, 01.10.1940., 13. lpp.; Cīna, 02.10.1940., 4. lpp.

${ }^{57}$ Gustava Ādolfa Celmiña studenta lieta. LNA LVVA, 7427-1-3546, 42 lp.

${ }^{58}$ RAIMONDS CERŪZIS. Latvieši un vācbaltieši starpkaru periodā: no kopīgas kultūras identitātes līdz "pieminekḷu karam”. In: Latvijas Vēstures Institūta Žurnāls 2015, Nr. 3, 65.-99. lpp., šeit 77.-78. lpp.

${ }^{59}$ Ibidem; ARvīDS RozentĀLS. Korporācijai Selonija 85 gadi. In: Londonas Avīze, 26.11.1965., 3. lpp.

${ }^{60}$ Augstskolas jautājums. In: Izglītība, 16.03.1919., 3. lpp.

${ }^{61}$ Ministru kabineta sēde [04.08.1919.]. In: Latvijas Sargs, 05.08.1919., 1. lpp.

${ }^{62}$ VANDA BRŪVele. Pauls Dāle. Dzīves lokos. In: Padomju Jaunatne, 22.07.1989., 4. lpp.; ZAIGA LAPIN̦A, AIJA PRIEDİTE. Uzticība garam... In: Karogs 1989, Nr. 7, 149. lpp.

${ }^{63}$ Ministru kabineta sēde [29.12.1919.]. In: Valdības Vēstnesis, 30.12.1919., 4. lpp.

${ }^{64}$ Viņa sieva īsi pirms Augstskolas atklāšanas aizsūtīja telegrammu uz Rīgu, ka vīrs Vācijā saslimis (Latvijas augstskolas rektors profesors Waldens. In: Latvijas Sargs, 27.09.1919., 3. 1pp.).

${ }^{65}$ FRICIS GULBIS. Vēl reiz "Valdena lietā". In: Latvijas Vēstnesis, 18.02.1924., 2. 1pp.; JURIS ZAḲIS. Nacionālās valstis un nacionālās universitātes. Referāts konferencē "Latvijas un Eiropas jaunās valstis: 1918-1939”, 06.11.1998. In: Latvijas Vēstnesis, 13.11.1998., 4. lpp.

${ }^{66}$ Latvijas augstskolas protests pret Bermonta uzbrukumu. In: Latvijas Sargs, 18.10.1919., 2. lpp.

${ }^{67}$ Latvijas nota par kara pieteikumu Vācijai, 25.11.1919. LNA LVVA, 2574-4-93, 122. lp.

${ }^{68}$ Georgs VīTols. Profesora Paula Valdena piemiṇai. In: Universitas 1957, Nr. 4, 71. lpp.; PAUL WALDEN. Wege und Herbergen: mein Leben. Hrsg. von Günter Kerstein. Wiesbaden 1974, S. 46-47.

${ }^{69}$ PAULS DĀLE (sast.). Vēsturisks pārskats par Latvijas Augstskolas nodibināšanu un vinas darbību pirmā (1919./20.) mācības gadā. Rīga 1921, 19. lpp.

${ }^{70}$ Sk., piem.: JĀNIS STRAdiN̦š. Trešā atmoda. Rīga 1992, 316.-331. lpp.; JĀNIS STRAdiN̦š. Akadēmiskā izglītība Baltijā un Latvijas Universitātes priekšvēsture. In: ALBERTS VARSLAVĀNS. (sast.). Latvijas Universitāte 75. Rīga 1994, 13.-44. lpp., šeit 40. lpp.

${ }^{71}$ Mācības līdzekḷi Latvijas Augstskolai. In: Latvijas Sargs, 12.08.1919., 1. lpp.; Mācības līdzekḷi Augstskolai. In: Latvijas Sargs, 17.08.1919., 1. lpp.; Profesors Valdens. In: Valdības Vēstnesis, 17.08.1919., 6. lpp.

${ }^{72}$ Polytechnikum. In: Rigasche Rundschau, 06.10.1905., S. 3; Aus der jüngsten Vergangenheit des Rigaschen Polytechnischen Instituts. In: Düna Zeitung, 07.09.1906., S. 1.

${ }^{73}$ Sarakste ar Rīgas apgabala Izglītỉbas pārvaldi par cīnu pret studentu saietiem u. c. (1904-1905). LNA LVVA, 7175-1-333, 166., 169., 179. 1p.

${ }^{74}$ P. Miḳelsons, Universitātes galvenais šveicars. In: Pēdējā Brīdī, 01.10.1935., 3. lpp.

${ }^{75}$ Auf der gestrigen Studentenversammlung. In: Rigasche Rundschau, 29.10.1905.; Acta des Verwaltungsrathes des Polytechnischen Instituts zu Riga betr. den Professor Gregor Schwartz. LNA LVVA, 7175-1-248, 50., 59. 1p.; Acta des Verwaltungsrathes des Polytechnischen Instituts zu Riga betr. den Docenten Alexander Döllen. Ibidem, 7175-1-200, 52.-54. lp.

${ }^{76}$ Acta des Verwaltungsrathes des Polytechnischen Instituts zu Riga betr. den ordentlichen Professor Paul Walden. LNA LVVA, 7175-1-274, 64. 1p.

${ }^{77}$ Ibidem, 91. lp.

${ }^{78}$ Das Rigaer Polytechnikum. In: Rigasche Zeitung, 17.07.1919., S. 1; WALDEN, Wege und Herbergen, S. 46-47. 
${ }^{79}$ Sk., piem.: Sarakste ar Rīgas apgabala Izglīiības pārvaldi par cīn,u pret studentu saietiem u. c. (1904-1905). LNA LVVA, 7175-1-329, 3., 150.-151., 256.-257., 449.-451., 492.-493., 522., 549.-551. lp.

${ }^{80}$ Latvijas izglītības biedrības augstskolu sekcijas sēde. In: Latvijas Sargs, 03.02.1920., 3. lpp.

${ }^{81}$ Rīga, Universitātes padomes sēde. In: Latvis, 22.02.1924., 5. lpp.; Profesors Valdens [lapas atvērums, veltīts vieslekcijas norisei Rīgā]. In: Nedēla, 09.05.1924., 5. lpp.

${ }^{82}$ GuLBIs, Vēl reiz "Valdena lietā".

${ }^{83}$ FRICIS GulBIS. Kāds vārds "Valdena lietā”. In: Latvijas Vēstnesis, 05.02.1924., 2. lpp.; GuLBIS, Vēl reiz "Valdena lietā".

${ }^{84}$ Ernests Rolavs, pa 1905. gada tekām. In: Kurzemes Vārds, 18.01.1940., 5. lpp.

${ }^{85}$ KĀRLIS BALODIS. Valdena lietā. In: Latvijas Vēstnesis, 09.02.1924., 6. lpp.; KĀRLIS BALODIS. Mans beigu vārds Valdena lietā. In: Latvijas Vēstnesis, 20.02.1924., 5. lpp.

${ }^{86}$ HenRIJS Simsons. Pauls Valdens. In: Latvijas Vēstnesis, 10.05.1924., 5. lpp.

${ }^{87}$ H. Simsons izveselıjies. In: Pirmdienas Rīts, 06.08.1928., 1. lpp.; JĀNIS ANDRUPS. Kas bija Henrijs Simsons? In: INESE AuZIN̦A-SMITA (red.). Latvieši Lielbritānijā. Londona 1995, 21.-24. lpp.

${ }^{88}$ DĀLE, Vēsturisks pārskats par Latvijas augstskolas nodibināšanu, 76. lpp.

${ }^{89}$ Ibidem.

${ }^{90}$ Likvidējama fakultāte. In: Sociāldemokrāts, 01.01.1928., 1. lpp.; Latvijas Sociāldemokrātiskās Strādnieku partijas jaunā programma. In: Sociāldemokrāts, 03.07.1930., 4. lpp.

${ }^{91}$ Izglītîbas ministrijas vadītāji no 1918.-1938. g. In: Audzinātājs. Paidagoǵiski sabiedrisks mēnešraksts 1938, Nr. 11, 578. lpp.

${ }^{92}$ Latvijas Universitāte 1919-1929. Latvijas Universitātes izdevums. Rīga 1929, 532.-533. lpp.

${ }^{93}$ LŪCiJA BĒrziñA-Felsberga. Profesors Ernests Felsbergs. Atmiņas. In: RANKA, Profesors Dr. phil. h. c. Ernests Felsbergs, 50.-76. lpp., šeit 61. lpp.

${ }^{94}$ Nacionālās apvienības kandidātu saraksts Nr. 4. In: Latvis, 08.02.1925.; BĒRZIN̦A-FELSBERGA, Profesors Ernests Felsbergs, 61. lpp.

${ }^{95}$ Miris profesors Dr. Kārlis Balodis. In: Sociāldemokrāts, 14.01.1931., 3. lpp.

${ }^{96}$ Latvijas Darba Savienības un Tautas Apvienības saraksts. In: Jaunā Diena, 30.09.1928., 4. lpp.

${ }^{97}$ Prof. K. Balodis miris. In: Latvijas Kareivis, 14.01.1931., 3. lpp.

98 Jokupēteri [karikatūra]. In: Svari, 31.10.1924., 350. lpp.

${ }^{99}$ Pamazām, palēnām... In: Svari, 29.11.1929., 378. lpp.; Zieǵeḷa glabātājs [karikatūra]. In: Svari, 28.06.1929., 207. lpp.; Dep. profesors K. Balodis atteicies no deputāta algas [karikatūra]. In: Svari, 15.03.1929., 83. lpp.

${ }^{100}$ Vakarējais lauvas. In: Svari, 13.02.1931., 50. lpp.; Sludinātājs Dr. P. Zālīte. In: Svari, 03.04.1931., 107. lpp.; Deputāta kaislība. In: Svari, 12.06.1931., 183. lpp.; Neticama lieta. In: Svari, 14.08.1931., 242.-243. lpp.

${ }^{101}$ Augusts Tentelis. Tautas vadoṇa dzīve un personība. In: Latvijas Vēstures Institūta Žurnāls 1937, Nr. 3, 325.-334. lpp., šeit 329.-330. 1pp.

102 JŪLIJS AUŠKĀPS. Latviešu gars un zinātne. In: Sējējs 1937, Nr. 11, 1129.-1136. lpp., šeit 1132., 1135. lpp.; JŪLIJS AUŠKĀPS. Par gara cīṇu. In: Sējējs 1936, Nr. 11, 1147.-1152. lpp.

${ }^{103}$ ARNOLDS SPEKKE. Atmiņas par Latvijas Universitātes Filoloǵijas un Filozofijas Fakultātes sākumiem un izveidošanos. In: Universitas 1966, Nr. 17, 5.-8. lpp.

104 J. Rainis - kandidāts uz Nobela prēmiju. In: Sociāldemokrāts, 19.02.1926., 1. lpp.; Raiṇa kandidatūra uz Nobela prēmiju. In: Sociāldemokrāts, 23.03.1926., 1. lpp.

${ }^{105}$ ARNO Jundze. Provinces drāma. Kā Raini Nobela prēmijai (ne)izvirzīja. In: Neatkarīgā Rīta Avīze, 23.02.2015., 10.-11. lpp. 
106 JundZe, Provinces drāma, 10.-11. 1pp.

${ }^{107}$ Nošāvuši greizi [par Raiņa virzī̌anu Nobela prēmijai]. In: Latvis, 27.03.1926., 1. lpp.; Vai tiešām Rainis - Nobela prēmijas laureāts? In: Latvijas Sargs, 17.03.1926., 2. lpp.; J. Rainis kā Nobela prēmijas kandidāts. In: Brīvā Zeme, 18.03.1926., 3. lpp.; Māksla. Par Raini. In: Brīvā Zeme, 22.03.1926., 3. lpp.

${ }^{108}$ Latvijas Universitāte 1919-1929, 178.-179. lpp.

${ }^{109}$ KĀRLIS DZIḶLEJA. Raiņa tēls mūsu literatūrā. In: Domas, 01.07.1930., 123.-128. lpp., šeit 127.-128. lpp.

${ }^{110}$ Noteikumi par militāro audzināšanu un militāro apmācību publiskās un privātās mācības iestādēs. In: Valdības Vēstnesis, 27.04.1937., 1. lpp.

${ }^{111}$ Apmācības plāni, programmas, noteikumi u. c. par studentu militāro audzināšanu un apmācību (1937-1940). LNA LVVA, 7427-6-232, 7. lp.

112 Ibidem, 186., 207., 246.-247. lp.

${ }^{113}$ Ibidem, 263., 164. lp.

${ }^{114}$ Dĩtrins A. LĒBers. Vācbaltiešu mācību spēki Latvijas Universitātē (1919-1941). In: RENĀTe Adolfi (sast.). 800 gadi. Mūsu kopējā Rīga. Vācbaltiešu autoru apcerējumi. Rīga 2001, 145.-164. lpp., šeit 146., 148. lpp.

${ }^{115}$ Deutsche Lehrkräfte der Universität nehmen Abschied. In: Rigasche Post, 22.10.1939., S. 3; Arī studijas pārtraukušie varēs iegūt zinātnisko grādu. In: Brīvā Zeme, 26.10.1939., 2. lpp.; Aizbraucēju skaits jau sasniedz 40585. In: Jaunākās Ziņas, 28.11.1939., 5. lpp.; LĒBERS, Vācbaltiešu mācību spēki Latvijas Universitātē (1919-1941), 149.-162. lpp.

116 [Sēru sludinājums par N. Reinicu]. In: Tēvija, 07.07.1941., 1. lpp.; Rīgas Centrālcietumā atrasti 98 upuri. In: Kurzemes Vārds, 09.07.1941., 1. lpp.; Par ko noslepkavoja latviešu patriotus. In: Daugavpils Latviešu Avīze, 18.07.1941., 1. lpp.

117 Zinātni - darba ḷaudīm! In: Cīṇa, 07.11.1944., 7. lpp.; LĒBERs, Vācbaltiešu mācību spēki Latvijas Universitātē (1919-1941), 154. lpp.

${ }^{118}$ Vācu tautības repatriējošo studentu saraksts (1939). LNA LVVA, 7427-6-232, 258. lp.

${ }^{119}$ Vācu tautības mācības spēki. In: Jaunākās Ziṇas, 21.10.1939., 15. lpp.; Deutsche Lehrkräfte der Universität nehmen Abschied. In: Rigasche Post, 22.10.1939., S. 3.

${ }^{120}$ Mūsu jauno zinātnieku kadrs sekmīgi aizstās aizbraucējus. In: Latvijas Kareivis, 05.11.1939., 1. lpp.

${ }^{121}$ Pirmie ārkārtējie profesori un mag̣istri. In: Brīvā Zeme, 12.10.1939., 2. lpp.

${ }^{122}$ Mūsu jauno zinātnieku kadrs sekmīgi aizstās aizbraucējus, 1. lpp.

\section{SUMMARY}

The University of Latvia was founded on the late summer of 1919 and opened its doors to the students on September 28. This happened shortly after the end of an important stage in Latvia's so-called freedom fight or War of Independence. From that moment on, the Baltic Germans, who had a leading influence in the history of the Baltics, gradually lost their authority. At the beginning of the university formation, the Baltic Germans also had a great influence in this educational institution. The University of Latvia inherited a lot from its predecessor, the Riga Polytechnic Institute. The new university also took over the principle of examinations typical of tsarist Russia (division of the study year into periods of active studies and exams). Most of the teaching staff were German speakers, but the language of lectures until the beginnings of new national university was Russian. 
The majority of former teachers of Latvian origin at the Riga Polytechnic Institute also appreciated German culture and identity. A typical example here is the director of the Institute and the first head of the Latvian University, professor of chemistry Paul Walden (Valdens). He did not believe that Latvians would be able to create their own university and science, and did not even consider it possible to conduct a proper study in Latvian. Very soon Baltic German teachers were supplemented with new Latvian employees. Some of them returned from abroad, others quickly formed a career in Latvia on the spot.

As in society, the interpretation of past events was a very important issue in Latvian professors' community. For the last fifty years, Latvians had systematically tried to achieve the same rights as the great nations of Europe. A particular tension was the 1905 revolution and its repression form local administration and institutions. This event also had an impact on the establishment of the university, since, for example, P. Walden was actively involved in the persecution of revolutionary students in Riga Polytechnic Institute. Now these students had become professors.

There are many similarities between the history of the Latvian state and the national university. We can observe the same stages of development in the history of the university and within the state as a whole. This applies to both the economic situation and politics. After the World War and the War of Independence, the Latvian economy, especially industry, had partially collapsed. The difficult economic situation had a negative impact on the university staff - its financial resources were insufficient; salaries were low, and professors could not even buy the bare sustenance. The significant financial resources of the predecessor of the University of Latvia, Riga Polytechnic Institute, disappeared during the war and could not be recovered. In the mid-1920s, the economic situation improved rapidly. Furthermore, the financial situation of the institution improved as it received a heritage from the entrepreneur Kristaps Morbergs, which included both financial resources and profitable real estate (for example, the best regional hotel in the northeastern Europe "Hotel de Rome" in the city of Riga along with its famous luxury restaurants). In the middle of the thirties, a professor was already a prestigious profession in Latvia. The professor's salary was comparable to the minister's salary. University professors made a significant contribution to strengthening the identity of the new state and actively participated in the political life. Many university lecturers were from different, mostly liberal, and centrist political parties (except social democrats), and became members of the parliament (Saeima). The first President of Latvia, lawyer Jānis Čakste, was also a professor at the University of Latvia. Later, during the years of authoritarianism, the teaching staff of the university formed Latvia's educational, scientifical and cultural policy. The professors at the university were all three ministers of education of the authoritarian period (professor of theology, dean of the faculty Ludvigs Adamovičs, professor of history, rector Augusts Tentelis, professor of chemistry, dean, rector Jūlijs Auškāps). Thus, the authority of the national higher education institution in the field of education policy during this period was indisputable, it can even be said that the education and science policy of the authoritarian period was shaped by the professors of the university. The University of Latvia even partly formed the entire ideology of authoritarianism in Latvia, including the so-called "leader cult" of authoritarian leader Kārlis Ulmanis. 